
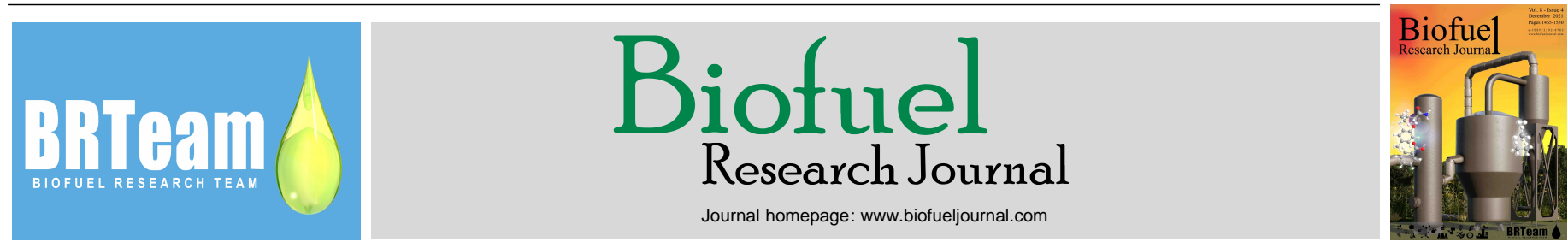

Review Paper

\title{
Yeast cell factories for sustainable whey-to-ethanol valorisation towards a circular economy
}

Patrícia Carvalho , Carlos E. Costa , Sara L. Baptista, Lucília Domingues*

Centre of Biological Engineering, University of Minho, Campus Gualtar, 4710-057, Braga, Portugal.

\section{HIGHLIGHTS}

$>$ Whey is the major by-product of the dairy industry, being an environmental concern.

$>$ Bioethanol is the prevalent product obtained from cheese whey fermentation.

$>$ Kluyveromyces sp. and Saccharomyces cerevisiae are the most used hosts for whey valorisation. $>$ Novel valorisation routes are rising due to the advances in metabolic engineering.

$>$ Integration of multi-valorisation pathways will positively impact process economics.

\section{GRAPHICAL ABSTRACT}

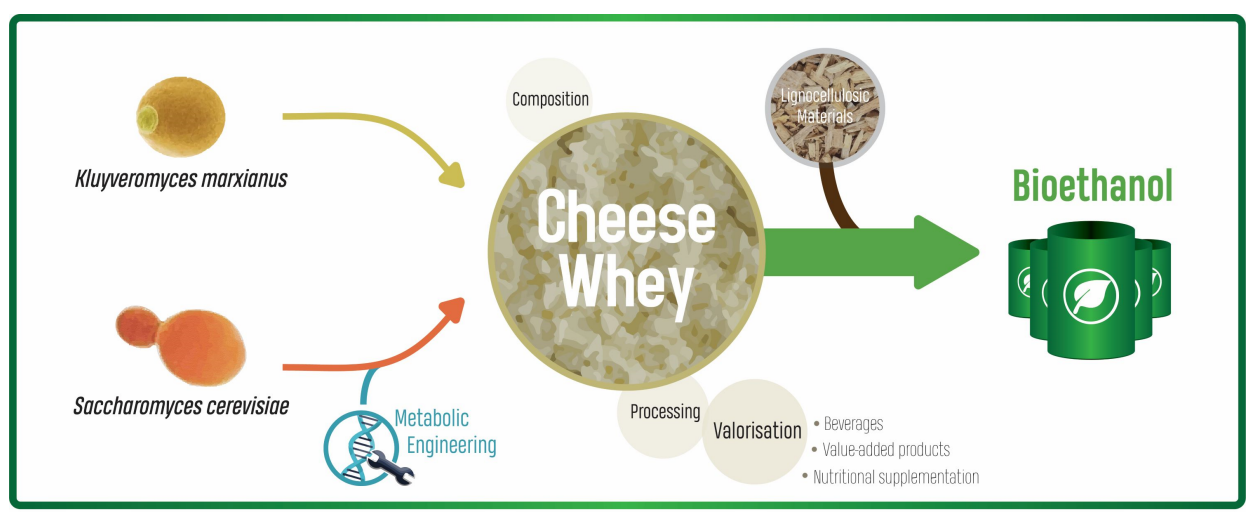

\section{ARTICLE INFO}

\section{Article history:}

Received 9 September 2021

Received in revised form 12 November 2021

Accepted 13 November 2021

Available online 1 December 2021

\section{Keywords:}

Cheese whey

Yeast fermentation

Metabolic engineering

Ethanol

Renewable carbon sources

\begin{abstract}
Cheese whey is the major by-product of the dairy industry, and its disposal constitutes an environmental concern. The production of cheese whey has been increasing, with 190 million tonnes per year being produced nowadays. Therefore, it is emergent to consider different routes for cheese whey utilization. The great nutritional value of cheese whey turns it into an attractive substrate for biotechnological applications. Currently, cheese whey processing includes a protein fractionating step that originates the permeate, a lactose-reach stream further used for valorisation. In the last decades, yeast fermentation has brought several advances to the search for biorefinery alternatives. From the plethora of value-added products that can be obtained from cheese whey, ethanol is the most extensively explored since it is the alternative biofuel most used worldwide. Thus, this review focuses on the different strategies for ethanol production from cheese whey using yeasts as promising biological systems, including its integration in lignocellulosic biorefineries. These valorisation routes encompass the improvement of the fermentation process as well as metabolic engineering techniques for the introduction of heterologous pathways, resorting mainly to Kluyveromyces sp. and Saccharomyces cerevisiae strains. The solutions and challenges of the several strategies will be unveiled and explored in this review.
\end{abstract}




\section{Contents}

1. Introduction.

2. Cheese whey composition, processing, and valorisation

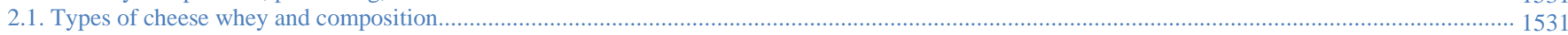

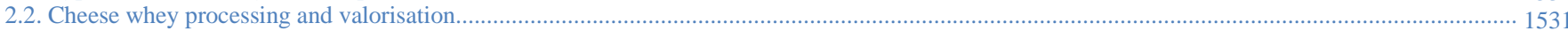

3. Ethanol production by cheese whey fermentation using yeast as a metabolic cell factory ...................................................................................... 1533

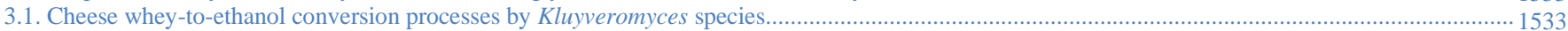

3.2. Exploiting Saccharomyces cerevisiae for cheese whey-to-ethanol valorisation................................................................................................. 1537

3.3. Incorporation of cheese-whey into lignocellulose biomass-to-ethanol processes............................................................................................... 1541

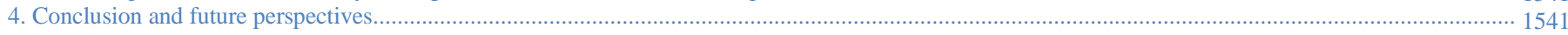

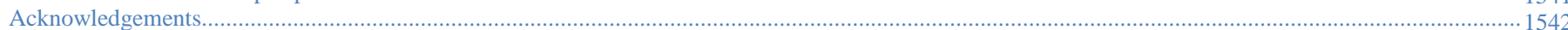

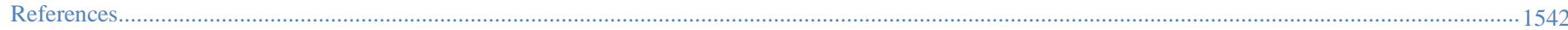

\begin{tabular}{|ll|}
\hline Abbreviations & \\
BOD & Biochemical oxygen demand \\
CMC & Carboxymethyl cellulose \\
COD & Chemical oxygen demand \\
GOS & Galacto-oligosaccharides \\
LCMs & Lignocellulosic materials \\
NPV & Net present value \\
RSM & Response Surface Methodology \\
WPC & Whey protein concentrate \\
WPH & Whey protein hydrolysate \\
WPI & Whey protein isolate \\
\hline
\end{tabular}

\section{Introduction}

Cheese whey is the major by-product of cheese processing in the dairy industry. It corresponds to the watery portion remaining after the coagulation of milk, and it is free of fat and casein. Cheese whey has a high nutritional value, with riboflavin (vitamin B12) responsible for its yellowish colour (Ryan and Walsh, 2016).

During cheese manufacturing, $9 \mathrm{~L}$ of cheese whey is generated for every 1 $\mathrm{kg}$ of cheese produced. According to the Food and Agriculture Organization, the production of cheese whey has been highly enlarged over the past years an increased rate of 3.8\% was observed between 2014 and 2018 (Smithers, 2015; FAO, 2020). In 2016, the worldwide production of whey from the cheese industry reached 190 million tonnes, and it is expected that its production will increase at the same rate of milk production, of $2 \%$ per year (Ryan and Walsh, 2016). With the rise in the consumption of cheese, higher volumes of cheese whey are also being formed, contributing to the intensification of industrial wastes.

The dairy industry sector is the main source of liquid waste in Europe, essentially due to the disposal of cheese whey (Demirel et al., 2005). The organic components of cheese whey are responsible for its highly polluting character. The Biochemical Oxygen Demand (BOD) and Chemical Oxygen Demand (COD) are key parameters used to characterize waste effluents. The COD value represents the amount of oxygen consumed in a particular biodegradation reaction, whereas BOD is related to the amount of dissolved oxygen necessary by aerobic biological organisms to degrade the organic matter of a mixture under specific conditions. The BOD and COD of cheese whey range between $30-60 \mathrm{~g} / \mathrm{L}$ and 50-102 $\mathrm{g} / \mathrm{L}$, respectively (Guimarães et al., 2010; Yadav et al., 2015; Ryan and Walsh, 2016). Together, COD and BOD give the Index of Biodegradability (BOD/COD) that indicates if a mixture can be easily degraded in the environment. The Index of Biodegradability of cheese whey is between 0.4 and 0.8 , which implies serious environmental problems. Moreover, the waste load of cheese whey is equivalent to 100-175 times the volume of domestic wastewater (Carvalho et al., 2013; Ryan and Walsh, 2016). Currently, most cheese whey surplus is used for animal feeding or spreading into the land, which constitutes an environmental problem. Cheese whey alters the soil composition and leads to an excess of oxygen consumption, impermeabilization, eutrophication, and toxicity in the environment where it is discarded. This compromises the growth of plants and decreases crop yields (Carvalho et al., 2013; Yadav et al., 2015). Furthermore, the available treatments to reduce the pollution load of cheese whey are not sufficient to efficiently reduce its environmental impact and imply high operational costs.

Due to the high volumes of cheese whey produced worldwide and the implied environmental hazards, it is urgent to develop new approaches to treat and/or reutilize cheese whey surplus in the dairy industry. The rising awareness of environmental problems and the increasing need for sustainability drive the research of recycling and reusing waste streams. This follows a circular economy system, where the products, materials, and resources are maintained in the economic system as long as possible to minimize the generation of waste (D'Amato et al., 2017; Álvarez-Cao et al., 2020). In Figure 1, a circular economy system for the valorisation of cheese whey surplus from the dairy industry is schematically represented. Novel integrated food biorefineries fed with cheese whey to generate functional foods with improved properties present solid perspectives and have been reviewed recently (Lappa et al., 2019). These food biorefineries follow the circular economy concept by allowing the reintroduction of produced bio-based food components in the food industry, aiming at zero waste discharge.

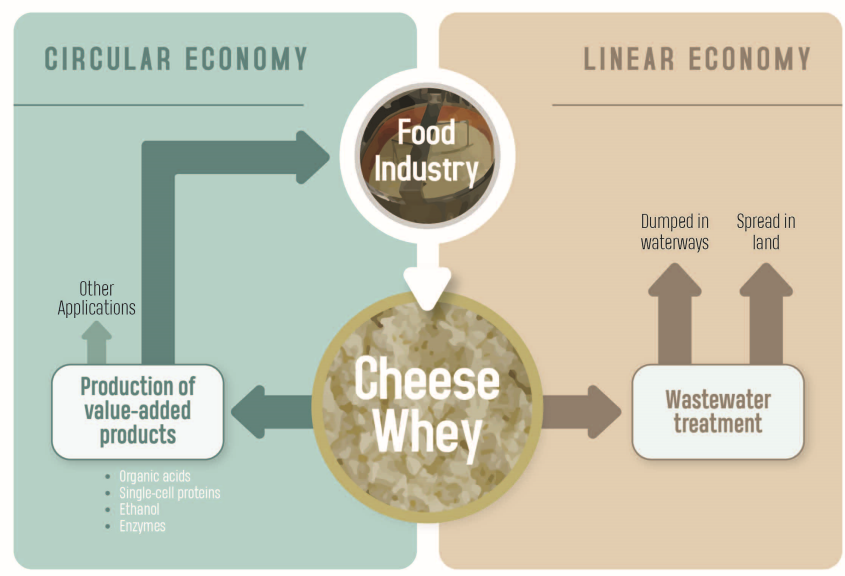

Fig. 1. Overview of whey utilization/valorisation for circular bio-economy system implementation.

In this sense, the high organic content of cheese whey represents a great potential to become an important resource that should be more broadly explored (Smithers, 2008). During the past years, several studies have addressed the valorisation of cheese whey through (1) the utilization of technology to recover valuable compounds, such as lactose, proteins, and derived compounds with different applications; and (2) the use of biological processes to generate value-added products such as ethanol, organic acids, single-cell proteins, enzymes, and bio-proteins (Prazeres et al., 2012; Mollea et al., 2013). Recently, cheese whey valorisation efforts gained a new driver with the need to develop biorefineries beyond the food industry. Biorefining is defined by the International Energy Agency as the sustainable processing of biomass into a spectrum of marketable products and energy. Biorefineries are classified in first, second and third-generation based on the different features of the feedstock. First-generation biomass 
comprises food or derived-food crops such as sugar cane or corn. These biomasses have a great sugar or starch content, being optimal to produce biofuels. However, the use of first-generation biomass is associated with socioeconomic and environmental issues such as price increases due to demand growth and soil deprivation due to over-fertilization (del Río et al., 2020). Lignocellulosic and algae biomass fed into second- and third-generation biorefineries, respectively, overcome the main disadvantage of first-generation feedstock, presenting a stable price with no need for extra land. Still, the lower carbon content compared to first-generation feedstocks becomes a bottleneck for biofuels production, particularly for bioethanol. Cheese whey, generated in high amounts and carbon content, has been recently applied in multi-waste valorisation approaches, boosting ethanol titres obtained in lignocellulosic biorefineries (Cunha et al., 2018 and 2021; Gomes et al., 2021a)

The basis of industrial biotechnology is the selection of optimal cell factories to establish a cost-competitive process. Significant progress has been made to develop yeast-based fermentation processes for converting cheese whey into fuels and chemicals. Some yeast strains, such as Kluyveromyces lactis, Kluyveromyces marxianus, Kluyveromyces fragilis (now considered a $K$. marxianus species, accordingly to the current nomenclature), and Candida pseudotropicalis, have been used as platform cell factories due to their natural ability to consume lactose (Guimarães et al., 2010). The yeast Saccharomyces cerevisiae, widely recognized as an ideal microbial cell factory to produce bioethanol (Cunha et al., 2020) and to be used in lignocellulosic biorefineries (Baptista et al., 2021), can also be tailored for the valorisation of cheese whey through lactose consumption (Guimarães et al., 2010).

Table 1 shows the various features of the present review compared to those of the reviews on cheese whey valorisation published in the last five years (2017-2021). While the majority of these focused on the use of microbial fermentation, the use of metabolic engineering strategies using yeast for bioethanol production is practically uncovered. This review spans the valorisation of cheese whey effluent using yeast as cell factories, covering metabolic engineering strategies for cheese whey surplus utilisation, and its integration in lignocellulosic biorefineries, for the production of value-added products, with a special focus on bioethanol.

Table 1.

Comparison of the coverage of the present review paper with those of the previously published reviews on the valorisation of cheese whey in the last five years (2017-2021).

\begin{tabular}{lccccc}
\hline Reference & $\begin{array}{l}\text { Microbial } \\
\text { fermentation }\end{array}$ & Yeast & $\begin{array}{l}\text { Metabolic } \\
\text { engineering }\end{array}$ & Bioethanol & $\begin{array}{c}\text { Biorefinery } \\
\text { integration }\end{array}$ \\
\hline This review & $\checkmark$ & $\checkmark$ & $\checkmark$ & $\checkmark$ & $\checkmark$ \\
Rao and Basak (2021) & $\checkmark$ & $\times$ & $\times$ & $\times$ & $\times$ \\
Pires et al. (2021) & $\times$ & $\times$ & $\times$ & $\times$ & $\times$ \\
Mangiagalli and Lotti & $\times$ & $\times$ & $\times$ & $\times$ & $\times$ \\
(2021) & $\checkmark$ & $\times$ & $\times$ & $\checkmark$ & $\checkmark$ \\
Asunis et al. (2020) & $\checkmark$ & $\times$ & $\checkmark$ & $\times$ & $\times$ \\
Zikmanis et al. (2020) & $\checkmark$ & $\times$ & $\times$ & $\times$ & $\times$ \\
Rocha and Guerra & $\checkmark$ & $\checkmark$ & $\times$ & $\checkmark$ & $\times$ \\
(2020) & $\checkmark$ & $\times$ & $\times$ & $\times$ & $\times$ \\
Addai et al. (2020) & $\checkmark$ & $\times$ & $\times$ & $\times$ & $\times$ \\
Dinika et al. (2020) & $\checkmark$ & $\times$ & $\times$ & $\times$ \\
Zotta et al. (2020) & $\checkmark$ & $\times$ & $\times$ & $\times$ & $\times$ \\
Rama et al. (2019) & $\checkmark$ & $\times$ & $\times$ & $\times$ & $\times$ \\
Wen-qiong et al. & $\times$ & $\times$ & $\times$ & $\times$ & $\times$ \\
(2019) & $\times$ & $\times$ & $\times$ & $\times$ \\
Nicolás et al. (2019) & $\times$ & $\times$ & $\times$ & $\times$ \\
Dinika and Utama \\
(2019)
\end{tabular}

\section{Cheese whey composition, processing, and valorisation}

\subsection{Types of cheese whey and composition}

Cheese whey is mainly composed of water (95\% of total whey volume), lactose (70-72\% of total solids), whey proteins (8-10\% of total solids) and minerals (12-15\% of total solids) (Ryan and Walsh, 2016). The exact composition of cheese whey is variable depending on the type of cheese whey, source of milk, and processing technology (Panesar et al., 2007; Pescuma et al., 2015). According to the technique used to remove casein from milk, cheese whey can be classified into sweet or acid whey. The sweet whey ( $\mathrm{pH}$ around 5.6) is obtained from a mixture of an industrial casein-clotting enzymatic complex called rennet (containing the protease chymosin), leading to the casein coagulation. This is the first step in cheese manufacturing, and it is used in most types of cheese production (Panesar et al., 2007). The acid whey $(\mathrm{pH}=4.5)$ results from the precipitation of casein, using a mixture of organic (lactic acid) and mineral acids (hydrochloric or sulphuric acid), or with the action of specific bacteria (Jelen et al., 2003). These two types of whey present differences in minerals content, acidity, and protein bulk (Yadav et al., 2015; Ryan and Walsh, 2016). As a rule of thumb, acid whey has higher ash and lower protein content than sweet whey (Carvalho et al., 2013).

Lactose is the main constituent of cheese whey, followed by other proteins, including $50-55 \%$ of $\beta$-lactoglobulin, $20-25 \%$ of $\alpha$-lactoalbumin, $10 \%$ of immunoglobulins, $5-10 \%$ of serum albumin, and small quantities of other proteins such as protease peptone, lactoferrin, lactoperoxidase and glycomacropeptide (Ryan and Walsh, 2016). In terms of minerals, more than $50 \%$ of the total minerals content is constituted by calcium, as well as sodium and potassium. Trace elements present in cheese whey include zinc and copper. Additional compounds can also be present in low quantities, like lactic and citric acids, non-protein nitrogen compounds (urea and uric acid), and B-group vitamins (Jelen et al., 2003; Ryan and Walsh, 2016) Thus, whey is a source of different and diverse compounds that can be directly used for several applications or be valorised through biotechnological processes.

\subsection{Cheese whey processing and valorisation}

Approximately $50 \%$ of the cheese whey produced worldwide is used as a supplement in animal feeding and as a land fertilizer or in food applications (ice creams, cakes, sauces, and derivatives) (Guimarães et al., 2010; Ryan and Walsh, 2016; Castillo et al., 2020).

The first step of cheese whey processing includes drying whey to obtain a whey powder form (González-Siso, 1996). The water content is reduced throughout a reverse osmosis process, followed by vacuum evaporation. After that, it is spray dried and crushed to obtain the powdered aspect. This allows to preserve the properties of whey for a long time, as well as to facilitate storage, manipulation, and transportation.

Proteins present in cheese whey (around 20\% of total milk proteins) are important sources of essential amino acids, especially sulfur-containing amino acids like methionine and cysteine, which are reported to act as nutraceuticals (Lappa et al., 2019). They present valuable properties for food and cosmetic applications, such as high solubility, water absorption, gelatinization, and emulsifying capacities (Gunasekaran et al., 2007). Currently, whey proteins are extensively used as a food ingredient and nutritional supplement for muscle building. They also present health benefits associated with their antioxidant, antihypertensive, and somniferous properties (Audic et al., 2003; Korhonen, 2009; Modler, 2009). Another interesting application of whey proteins is for bioactive peptides production via enzymatic or fermentative processes (Yadav et al., 2015). Considering these advantageous properties, the application of technologies to recover the protein fraction, such as ultracentrifugation or membrane-based systems, is well established in the dairy industry (Pouliot, 2008). The resulting concentrated protein fraction can be treated to originate three different protein whey powders: whey protein concentrate (WPC), whey protein isolate (WPI), and whey protein hydrolysate (WPH) (Smithers, 2008; Álvarez-Cao et al., 2020). Due to its high nutritional properties, concentrate whey powder has a commercial value 3 to 40 times higher than whey powder (Mollea et al., 2013), and it can be subjected to several purification steps to obtain the purified proteins. 
The permeate is a lactose-rich stream resultant from the protein fractionating process. This fraction contains $70 \%$ of the total solids of whey and still represents an environmental problem (Ryan and Walsh, 2016). Whey permeate can be directly used in human nutrition due to its oligosaccharides content (Barile et al., 2009; Mollea et al., 2013) or be subjected to a lactose recovery process by crystallization (Paterson, 2009). Lactose is used for baby milk formulation, as an excipient in the pharmaceutical industry, and also to produce added-lactose derivatives, such as lactulose, lactitol, lactobionic acid, lactosyl urea, galacto-oligosaccharides, and lactosucrose (González-Siso, 1996; Guimarães et al., 2010; Álvarez-Cao et al., 2020). Alternatively, lactose can be hydrolysed to originate a mixture of glucose and galactose for lactose-free dairy products or can be used as food sweeteners (Gänzle et al., 2008). Another application for lactose in cheese whey or whey permeate is the production of functional beverages. It can be mixed with fruit juice/pulp to obtain fruit-whey beverages - a mineral and vitamin-enriched product that combines the beneficial effects of whey and fruits (Zotta et al., 2020). Alternatively, whey or permeate can be converted into functional beverages through microbial fermentation using a consortium of lactic acid bacteria and yeast strains. The fermentation of lactose results in whey acidification (due to lactic acid production) and the formation of compounds such as acetaldehyde and diacetyl. These compounds are responsible for the aroma and flavour of beverages and improve beverages' shelf life and sensorial properties, respectively (Mudgil and Barak, 2019; Zotta et al., 2020). Furthermore, during fermentative processes, bioactive peptides are also produced, enhancing the functionality of the wheybased beverages (Brandelli et al., 2015). Cheese whey is also a potential raw material for the production of alcoholic beverages. Dragone et al. (2009) developed an alcoholic distilled beverage by continuous fermentation of cheese whey using $K$. marxianus. The volatile composition analysis of the produced drink identified compounds similar to those present in other alcoholic beverages (Dragone et al., 2009). Fermentation of whey has also been used to produce kefir-like whey beverages. The classical method to produce kefir involves milk fermentation using kefir grains, which contain a stable mixture of bacterial and yeast species (Magalhães et al., 2010). The utilization of these grains as starting culture for cheese whey and deproteinised cheese whey fermentation produced ethanol, acids (lactic and acetic), higher alcohols (2-methyl-1-butanol, 3-methyl-1-butanol, 1hexanol, 2-methyl-1-propanol, and 1-propanol), ethyl acetate, and acetaldehyde, in similar amounts of those obtained during milk fermentation (Magalhães et al., 2011a). These results and the beverages' acceptance in the sensory analysis (Magalhães et al., 2011b) demonstrate the potential of utilizing both cheese whey and deproteinised cheese to produce kefir-like beverages, which constitutes a new valorisation route Besides its high lactose content, cheese whey and permeate present essential nutrients beneficial for microbial growth, and therefore can be used as a fermentation medium (Panesar et al., 2007). An overview of the processing of cheese whey, its applications, and valorisation paths is shown in Figure 2. Instead of a waste stream with a high polluting load, whey and permeate are increasingly recognized as a source of value-added products. Those include bacterial cellulose (Rollini et al., 2020; Lappa et al., 2021), aminoacids (Carranza-Saavedra et al., 2021), polymers (Obruca et al., 2011; Pais et al., 2016; Hou et al., 2021) or organic acids (Nayak and Pal, 2013; Jiang et al., 2015; Pandey et al., 2019; Nagarajan et al., 2020; Omwene et al., 2021) (Table 2). While this review focuses on yeast microbial valorisation of cheese whey using diverse microorganisms such as bacteria and/or filamentous fungi have also been accomplished. Although these microorganisms are suitable to yield valuable chemicals, yeast-based fermentation processes have been widely explored for wheyto-ethanol valorisation.

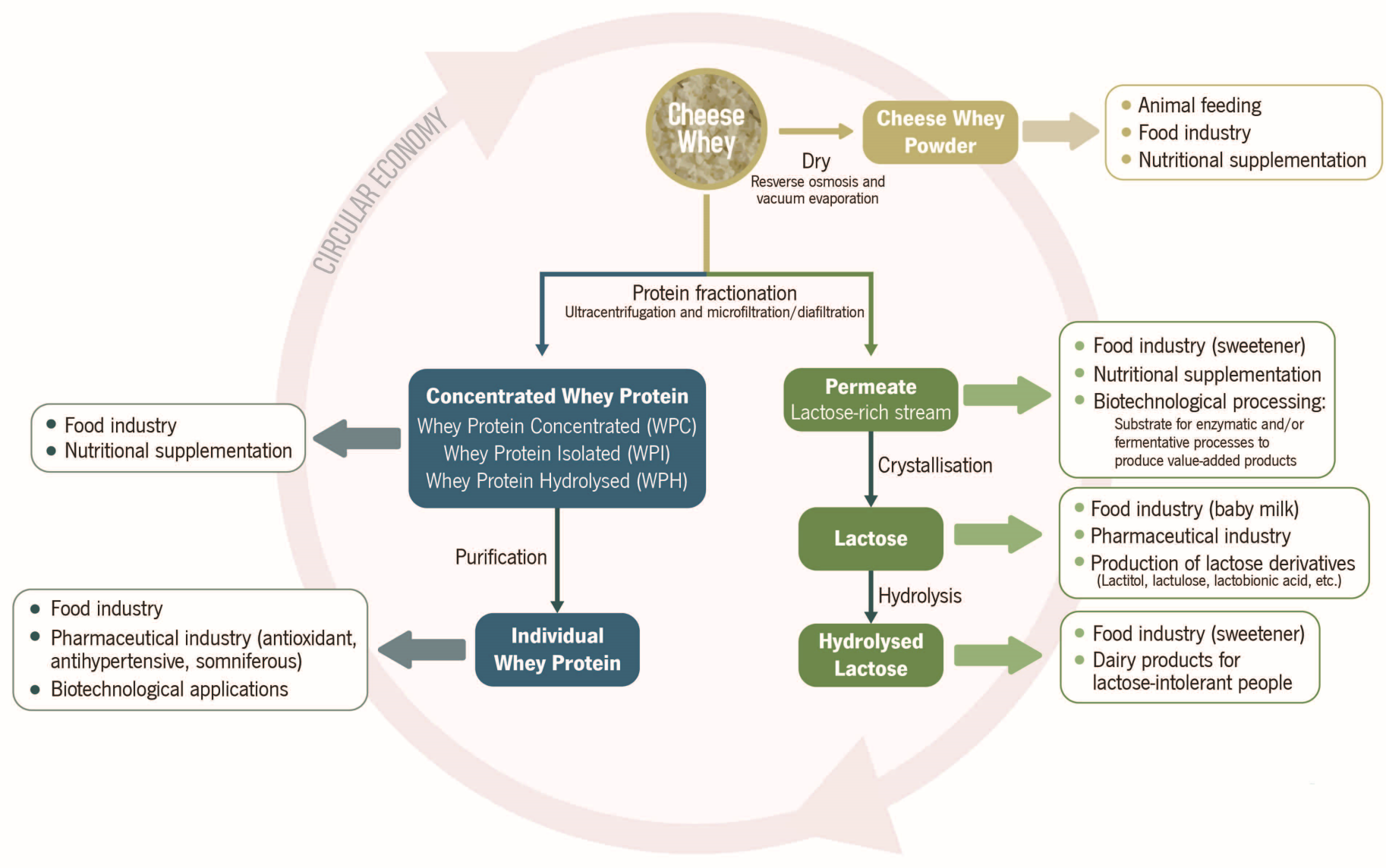

Fig. 2. Overview of cheese whey processing and its different applications. 
Table 2.

Examples of value-added compounds obtained from cheese whey substrate by non-yeast fermentation.

\begin{tabular}{|c|c|c|c|}
\hline Product & Microorganism & $\begin{array}{c}\text { Genetic } \\
\text { modifications }\end{array}$ & Reference \\
\hline Lactic acid & $\begin{array}{l}\text { Lactobacillus } \\
\text { plantarum }\end{array}$ & $x$ & Nagarajan et al. (2020) \\
\hline \multirow{2}{*}{$\begin{array}{l}\text { Polyhydroxybutyrate } \\
\text { (PHB) }\end{array}$} & Escherichia coli & $\checkmark$ & Hou et al. (2021) \\
\hline & Bacillus megaterium & $x$ & Obruca et al. (2011) \\
\hline $\begin{array}{l}\text { Poly(3-hydroxybutyrate- } \\
\text { co-3-hydroxyvalerate) }\end{array}$ & Haloferax mediterranei & $x$ & Pais et al. (2016) \\
\hline $\begin{array}{l}\text { Sakacin-A + } \\
\text { Bacterial cellulose }\end{array}$ & $\begin{array}{l}\text { Komagataeibacter } \\
\text { xylinus and } \\
\text { Lactobacillus sakei }\end{array}$ & $x$ & Rollini et al. (2020) \\
\hline L-valine & Escherichia coli & $\checkmark$ & $\begin{array}{l}\text { Carranza-Saavedra et al } \\
(2021)\end{array}$ \\
\hline Succinic acid & $\begin{array}{l}\text { Actinobacillus } \\
\text { succinogenes }\end{array}$ & $x$ & Omwene et al. (2021) \\
\hline $\begin{array}{l}\beta \text {-galactosidase }+ \\
\text { Bacterial cellulose }\end{array}$ & $\begin{array}{l}\text { Aspergillus awamori } \\
\text { and Acetobacter } \\
\text { xylinum }\end{array}$ & $x$ & Lappa et al. (2021) \\
\hline $\begin{array}{l}\text { Biohydrogen + Organic } \\
\text { acids }\end{array}$ & $\begin{array}{l}\text { Lactobacillus } \\
\text { acidophilus }\end{array}$ & $x$ & Pandey et al. (2019) \\
\hline Acetic acid & Acetobactor aceti & $x$ & Nayak and Pal (2013) \\
\hline Propionic acid & $\begin{array}{l}\text { Propionibacterium } \\
\text { acidipropionici }\end{array}$ & $\checkmark$ & Jiang et al. (2015) \\
\hline
\end{tabular}

\section{Ethanol production by cheese whey fermentation using yeast as a metabolic cell factory}

While ethanol is the most prevalent product from cheese whey, an alternative range of value-added compounds can also be produced from this substrate, and several studies have developed yeast-based processes in this sense (Table 3). The first reports for cheese whey valorisation for non-ethanol products using yeast (Kluyveromyces sp.) started more than three decades ago, aiming to produce citric acid (Abou-Zeid et al., 1983), glycerol (Jenq et al., 1989; Rapin et al., 1994), and the enzyme polygalacturonase (Donaghy and McKay, 1994; Gomez-Ruiz et al., 1988). Since then, the focus has mainly shifted to products with high industrial interest like lipids for biodiesel production (Castanha et al., 2014; Taskin et al., 2015; Vyas and Chhabra, 2019), organic acids like lactic acid (Plessas et al., 2008; Turner et al., 2017), or prebiotics, such as lactulose (de Freitas et al., 2020).

Most studies aim to utilize yeast naturally capable of fermenting lactose, therefore not having any genetic modifications. A wide range of microorganisms has already been used in this sense, like K. marxianus (Schultz et al., 2006; Bansal et al., 2008; Petrova and Kujumdzieva, 2010) or K. lactis (You et al., 2017), Yarrowia lipolytica (Taskin et al., 2015), Meyerozyma guilliermondii (Knob et al., 2020), among many others. Other approaches focus on the advantages of mixed cultures of K. marxianus and Candida krusei to produce single-cell proteins (Yadav et al., 2014) or the triple synergy between K. marxianus, Lactobacillus delbrueckii ssp. Bulgaricus and Lactobacillus helveticus to produce lactic acid (Plessas et al., 2008).

Alternatively, other studies have employed metabolic engineering strategies to attain the production of a plethora of compounds. These mainly focused on the introduction of heterologous pathways for the production of compounds like lactic (Turner et al., 2017) and ascorbic acids (Rosa et al., 2013), $\beta$ Carotene (Nasrabadi and Razavi, 2011), tagatose (Wanarska and Kur, 2012; Liu et al., 2019), or enzymes, especially $\beta$-galactosidase (Domingues et al., 2005; Álvarez-Cao et al., 2020). Additionally, some of these products can be coupled with ethanol production, as is the case for $\beta$-galactosidase production (Domingues et al., 2005; You et al., 2017), which may help to improve process feasibility and implementation. An example of an integrated process is schematically represented in Figure 3.

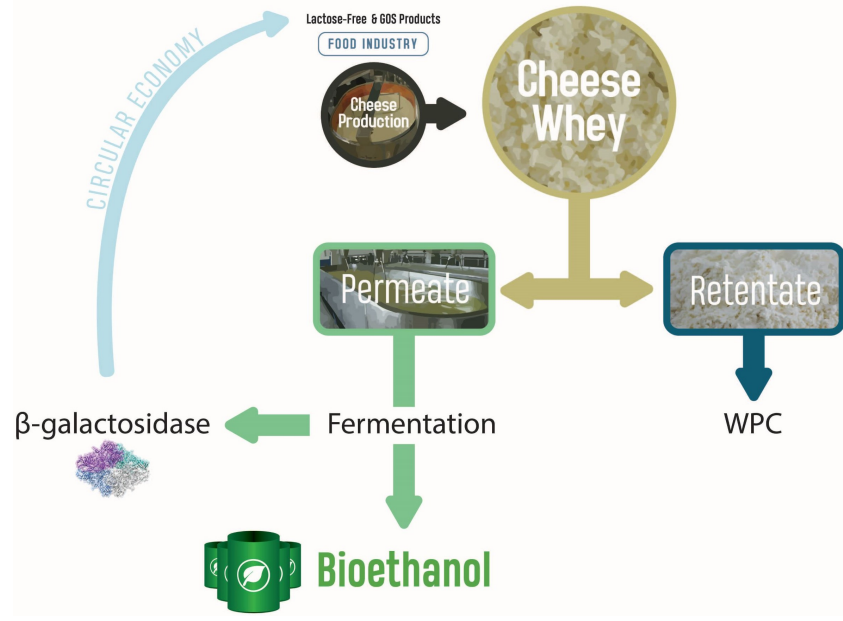

Fig. 3. Schematic presentation of an integrated cheese whey valorisation process with simultaneous production of bioethanol and $\beta$-galactosidase. WPC: whey protein concentrate; GOS: Galacto-oligosaccharides.

Ethanol $\left(\mathrm{C}_{2} \mathrm{H}_{6} \mathrm{O}\right)$, naturally produced by the fermentation of sugars, is mainly used as raw material for pharmaceutical, cosmetical, and solvent industries. Under its potable form, it can also be used to produce alcoholic beverages (Ryan and Walsh, 2016). Bioethanol constitutes the alternative biofuel most used worldwide since it reduces the environmental impacts of fossil fuels, in particular greenhouse gas emissions (Balat, 2011; Cunha et al., 2018). The high lactose content of cheese whey suggests its utilization for bioconversion into ethanol, as shown in Equation 1.

$\mathrm{C}_{12} \mathrm{H}_{22} \mathrm{O}_{11}+\mathrm{H}_{2} \mathrm{O} \rightarrow 4 \mathrm{CH}_{3} \mathrm{CH}_{2} \mathrm{OH}+4 \mathrm{CO}_{2}$

Eq. 1

The theoretical yield is equal to $0.538 \mathrm{~g}$ ethanol/g lactose consumed. Thus, cheese whey represents another renewable feedstock for the production of biofuels.

Although cheese whey is not economically competitive with the substrates currently used for first-generation biofuels, this raw material presents numerous advantages. First of all, being a by-product that can be reused, it reduces competition for traditionally used food crops, such as corn-starch or sugarcane (Zhou et al., 2019). Secondly, its utilization decreases the pollution load associated with its disposal (Murari et al. 2019). Indeed, cheese whey is a low-cost and abundant substrate that does not require extensive pre-processing such as lignocellulosic materials (e.g., high temperature, acid treatments) (Ryan and Walsh, 2016). However, the direct fermentation of cheese whey for ethanol production is limited by the low lactose content of cheese whey, around 5\%, which results in ethanol titers of $2-3 \%(\mathrm{v} / \mathrm{v})$, increasing distillation costs (Farkas et al., 2019). Thus, it is important to concentrate lactose in cheese whey, using ultrafiltration and/or reverse osmosis technologies (Guimarães et al., 2010). Another alternative proposed more recently is to increase the sugar concentration by mixing with other sugar-enriched materials, such as molasses (Álvarez-Cao et al., 2020). Conversely, cheese whey may also be used to increase the carbon content of lignocellulosic biomasses (Cunha et al., 2018; Cunha et al., 2021) and has been shown to positively contribute to lignocellulosic bioethanol production by nutritional supplementation (Kelbert et al., 2015)

\subsection{Cheese whey-to-ethanol conversion processes by Kluyveromyce species}

One of the most attractive aspects of Kluyveromyces sp. is their capacity to ferment lactose. This ability involves two proteins: lactose permease (encoded by $L A C 12$ gene) and a $\beta$-galactosidase (encoded by $L A C 4$ gene). The lactose permease is a membrane protein with 587 amino acids responsible for lactose uptake into the cells (Boze et al., 1987). This 
Table 3.

Main value-added compounds obtained from cheese whey substrate by yeast fermentation.

\begin{tabular}{|c|c|c|c|c|}
\hline Class & Product & Microorganism & Genetic modifications & Reference \\
\hline \multirow[b]{2}{*}{ Alcohols } & \multirow[b]{2}{*}{ Glycerol } & \multirow[b]{2}{*}{ Kluyveromyces marxianus } & $\times$ & Jenq et al. (1989) \\
\hline & & & $\times$ & Rapin et al. (1994) \\
\hline \multirow{12}{*}{ Enzymes } & \multirow{8}{*}{$\begin{array}{c}\beta \text {-Galactosidase and } \\
\alpha \text {-Galactosidase }\end{array}$} & \multirow{3}{*}{ Kluyveromyces marxianus } & $\times$ & Bansal et al. (2008) \\
\hline & & & $x$ & Perini et al. (2013) \\
\hline & & & $x$ & Kaur et al. (2015) \\
\hline & & \multirow{2}{*}{ Kluyveromyces lactis } & $\times$ & You et al. (2017)* \\
\hline & & & $\checkmark$ & Álvarez-Cao et al. (2018) \\
\hline & & Kluyveromyces sp. & $x$ & Kumari et al. (2019) \\
\hline & & Saccharomyces fragilis & $x$ & Bosso et al. (2019) \\
\hline & & Saccharomyces cerevisiae & $\checkmark$ & Domingues et al. (2005)* \\
\hline & Lipase & Meyerozyma guilliermondii & $\times$ & Knob et al. (2020) \\
\hline & \multirow[b]{2}{*}{ Polygalacturonase } & \multirow[b]{2}{*}{ Kluyveromyces marxianus } & $x$ & Gomez-Ruiz et al. (1988) \\
\hline & & & $\times$ & Donaghy and McKay (1994) \\
\hline & Cutinase-like enzyme & Pseudozyma antarctica & $\times$ & Watanabe et al. (2014) \\
\hline \multirow{10}{*}{ Oils } & \multirow{8}{*}{ Lipids } & \multirow[b]{2}{*}{ Cryptococcus laurentii } & $\times$ & Castanha et al. (2014) \\
\hline & & & $\times$ & Carota et al. (2017) \\
\hline & & \multirow{2}{*}{ Cryptococcus curvatus } & $x$ & Seo et al. (2014) \\
\hline & & & $\times$ & Carota et al. (2017) \\
\hline & & Yarrowia lipolytica & $\times$ & Taskin et al. (2015) \\
\hline & & Debaryomyces etchellsii & $x$ & Arous et al. (2016) \\
\hline & & Wickerhamomyces anomalus & $x$ & Arous et al. (2017) \\
\hline & & Cystobasidium oligophagum & $\times$ & Vyas and Chhabra (2019) \\
\hline & \multirow{5}{*}{ Single Cell Proteins } & Cryptococcus curvatus and Candida & $\times$ & Daniel et al. (1999) \\
\hline & & bombicola & $x$ & Otto et al. (1999) \\
\hline \multirow{3}{*}{ Single Cell Proteins } & & Kluyveromyces fragilis & $\times$ & Mansour et al. (1993) \\
\hline & & Kluyveromyces marxianus & $\times$ & Schultz et al. (2006) \\
\hline & & $\begin{array}{l}\text { Mixed cultures of Kluyveromyces } \\
\text { marxianus and Candida krusei }\end{array}$ & $x$ & Yadav et al. (2014) \\
\hline \multirow{6}{*}{ Sugars / prebiotics } & \multirow{3}{*}{ Tagatose } & Pichia Pastoris & $\checkmark$ & Wanarska and Kur (2012) \\
\hline & & & & \\
\hline & & Saccharomyces cerevisiae & $\checkmark$ & Liu et al. (2019) \\
\hline & & & & \\
\hline & Lactulose & Kluyveromyces lactis & $x$ & de Freitas et al. (2020) \\
\hline & Galacto-oligosaccharides & Kluyveromyces marxianus & $\times$ & Petrova and Kujumdzieva (2010) \\
\hline \multirow{6}{*}{ Organic acids } & Ascorbic acid & Kluyveromyces lactis & $\checkmark$ & Rosa et al. (2013) \\
\hline & \multirow{3}{*}{ Citric acid } & Candida lipolytica & $\times$ & Abou-Zeid et al. (1983) \\
\hline & & & & \\
\hline & & Yarrowia lipolytica & $\times$ & Arslan et al. (2016) \\
\hline & \multirow[t]{2}{*}{ Lactic acid } & $\begin{array}{l}\text { Mixed cultures of Kluyveromyces } \\
\text { marxianus, Lactobacillus } \\
\text { delbrueckii ssp. Bulgaricus }\end{array}$ & $x$ & Plessas et al. (2008) \\
\hline & & Saccharomyces cerevisiae & $\checkmark$ & Turner et al. (2017) \\
\hline $\begin{array}{l}\text { Aromatic } \\
\text { compounds }\end{array}$ & $\beta$-Carotene & Rhodotorula acheniorum & $\checkmark$ & Nasrabadi and Razavi (2011) \\
\hline
\end{tabular}

*Coupled with ethanol production.

Please cite this article as: Carvalho P., Costa C.E., Baptista S.L., Domingues L. Yeast cell factories for sustainable whey-to-ethanol valorisation towards a circular economy. Biofuel Research Journal 32 (2021) 1529-1549. DOI: 10.18331/BRJ2021.8.4.4 
transporter is inducible by intracellular levels of lactose and galactose. It is also an active transporter system that requires energy and can transport lactose against the concentration gradient (Domingues et al., 2010). The $\beta$ galactosidase, also known as lactase, is a cytosolic protein with 1032 amino acids (Poch et al., 1992) that hydrolyses lactose into glucose and galactose. These two monosaccharides are easily metabolized through glycolysis and the Leloir pathway, respectively. In addition, Kluyveromyces sp. are generally regarded as safe (GRAS) thermotolerant yeast with less stringent catabolite repression (Guimarães et al., 2010). The catabolite repression is a mechanism of gene expression in response to carbohydrate availability - in the presence of glucose, the genes for galactose metabolism (GAL genes) are not expressed; hence galactose is not used as a carbon source. Even though $K$. marxianus has more relieving catabolite repression, some studies addressed this effect to abolish it. The use of 2-deoxyglucose as a selective agent allowed the development of a $K$. marxianus strain (KD-15) which is less sensitive to glucose repression by adaptive evolution (Oda and Nakamura, 2009).

Despite several research efforts devoted to the utilization of cheese whey as a source of lactose by Kluyveromyces sp., only a few works focus on ethanol production. The fermentation capacity of Kluyveromyces sp. is lower than $S$. cerevisiae, leading to lower ethanol yields and consequent higher distillation costs (Pescuma et al., 2015). Indeed, Kluyveromyces sp. is more sensitive to osmolytes, which constitutes a disadvantage. These strains are mostly used for heterologous protein production or other biotechnological-related applications, as shown in Table 3 (van Ooyen et al., 2006).

To maximize ethanol production by Kluyveromyces sp., several factors that influence the fermentation process have been studied and optimized. Considering that Kluyveromyces sp. is sensitive to the osmotic effect, high lactose concentrations $(100-150 \mathrm{~g} / \mathrm{L})$ result in slower and rarely complete lactose fermentations (Zafar and Owais, 2006; Guimarães et al., 2010). It was postulated that high substrate concentration leads to a decrease in membrane fluidity that causes cell atrophy and organelle dehydration (Diniz et al., 2014; Díez-Antolínez et al., 2018). Another explanation is that high substrate concentrations repress sugar utilization due to high osmotic pressure (Farkas et al., 2019). This encompasses a great disadvantage since a reduced consumption of lactose inevitably leads to lower ethanol production. The osmotic sensitivity of Kluyveromyces sp. is not only noticeable at high substrate concentration but also at high product concentration. As ethanol amount increases, the growth rate and fermentative capacity decrease, leading to low ethanol productivity (Zafar and Owais, 2006). It was observed that the growth of $K$. marxianus CCT 7735 is severely reduced when ethanol concentration is higher than $4 \%(\mathrm{v} / \mathrm{v})$ (Silveira et al., 2005; Costa et al., 2014). Also, an increase in the levels of valine and metabolites of the citric acid cycle was observed in $K$. marxianus cells under stress at high ethanol concentrations (Silveira et al., 2020).

Although most fermentations reported in the literature are performed in batch conditions, there are some interesting results with different fermentation systems, such as semi-continuous fermentation. The constant replacement of culture media by fresh media decreases the catabolic repression as well as the substrate inhibition effect, the central hindrances of ethanol production (Zohri et al., 2017). Another study reported a semi-continuous fermentation with $K$. marxianus CBS 712, resulting in higher ethanol titres $(19.32 \mathrm{~g} / \mathrm{L})$ than batch fermentation $(15.90 \mathrm{~g} / \mathrm{L})$. This improvement resulted from shortened lag phase and other non-ethanol productive phases in semi-continuous fermentation (Zoppellari and Bardi, 2013).

Nutrient availability can also play a key role in terms of fermentation performance. Koushki et al. (2012) observed an increase in ethanol production (from $5.1 \%$ to $5.8 \% \mathrm{v} / \mathrm{v}$ ) and lactose utilization rate (almost $10 \%$ ) in the presence of growth supplements (Table 4) (Koushki et al., 2012). Ergosterol and linoleic acid supplementation increased the fermentation capacity of Kluyveromyces sp., decreasing the fermentation time by almost $30 \mathrm{~h}$ (Janssens et al., 1983). This effect is in accordance with the role of sterols in ethanol tolerance (You et al., 2003; Aguilera et al., 2006).

Cell immobilization techniques have become an interesting strategy to increase fermentative capacity and surpass some batch-fermentation restrictions. The main advantage of using a matrix to immobilize cells is to overcome the product inhibition effect caused by higher ethanol concentrations. This approach allows a higher cell concentration per unit of reactor volume, reducing the fermentation time and increasing productivity. In addition, cells immobilized reactors showed long-term stability and an increased molecular selectivity (Díez-Antolínez et al., 2016; Gabardo et al., 2012; Soupioni et al., 2013). Christensen et al. (2011) performed a continuous fermentation with $K$. marxianus DSMZ 7239 immobilized in sodium-alginate beads, reaching the highest reported productivity $(4.5 \mathrm{~g} / \mathrm{L} \cdot \mathrm{h})$ (Table 4$)$. Although most studies of immobilized cells are performed in alginate beads, other materials have also been exploited. Roohina et al. (2016) immobilized $K$. marxianus cells in carboxymethyl cellulose (CMC) polymer and synthesized a copolymer of CMC with N-vinyl-2-pyrrolidone (CMC-gPVP). Ultimately, a continuous ethanol fermentation in a packed-bed immobilized cell reactor resulted in an ethanol production yield of $0.49 \mathrm{~g} / \mathrm{g}$, corresponding to $91.07 \%$ of theoretical yield (Table 4) (Roohina et al. 2016).

An advantage of $K$. marxianus in comparison with $S$. cerevisiae is its ability to ferment at high temperatures. Thermotolerance is an important factor for the biotechnology industry (Pinheiro et al., 2020). It reduces the costs associated with cooling and allows to obtain the ethanol directly from the broth by continuous evaporation at low pressure (Fonseca et al., 2008; Zoppellari and Bardi, 2013). While some $K$. marxianus can grow at temperatures as high as $52^{\circ} \mathrm{C}$, efficient fermentation is reported to occur up to $45^{\circ} \mathrm{C}$ (Abdel-Banat et al., 2010). However, most of the $K$. marxianus studies refer to a range of 32 to $35^{\circ} \mathrm{C}$ as optimal temperature to maximize ethanol production (Dragone et al., 2011; Koushki et al., 2012; Zoppellari and Bardi, 2013; Diniz et al., 2014; Murari et al., 2019).

Although fermentation is an anaerobic process, some yeasts still ferment even in the presence of oxygen and high glucose concentration - a phenomenon known as the Crabtree effect, which occurs in $S$. cerevisiae. Other yeast strains, like Kluyveromyces sp., are Crabtree-negative, i.e., they favour respiration over fermentation when oxygen is available, even at low concentrations (Yadav et al., 2015). It is known that a small amount of oxygen is needed to maximize ethanol production, as oxygen provides the energy required to produce essential biomolecules, such as amino acids, fatty acids, and sterols, indispensable for fermentative metabolism. Thus, oxygen availability should be high enough to allow anabolism but low enough to avoid excessive cell growth and oxidative metabolism (Zara et al., 2009). Zoppellari and Bardi (2013) reported higher ethanol yield using K. marxianus CBS 712 in anaerobiosis than in aerobiosis conditions (Table 4). This effect was justified with the high nutritional value of cheese whey, which can supply the needs of the yeast (Zoppellari and Bardi, 2013). Several other studies addressed the influence of oxygen availability in the metabolism of either K. marxianus (Castrillo and Ugalde, 1993; Castrillo et al., 1996) and K. lactis (González-Siso, 1996; Breunig et al., 2000; Goffrini et al., 2002; Snoek and Steensma, 2006), leading to the same observations

Another factor for ethanol production is the type and source of cheese whey. As aforementioned, cheese whey can be used in several forms, such as raw cheese whey, whey powder, deproteinized whey, among others (Zafar and Owais, 2006; Dragone et al., 2011; De Felice et al., 2012). Sansonetti et al. (2009) tested the effect of different types of cheese whey (raw cheese whey, cheese whey permeate and ricotta cheese whey) as substrates in batch fermentation under anaerobic conditions. The highest ethanol yield ( $97 \%$ of the theoretical value) was reached by using ricotta cheese whey, in comparison with the $83 \%$ achieved from raw cheese whey (Table 4) (Sansonetti et al., 2009). The higher ethanol yields can be correlated with the lower amount of proteins in cheese whey from ricotta A lower protein content drives the yeast metabolism more efficiently to fermentation instead of respiration. When the amount of protein is higher in the substrate, the yeast takes longer to start ethanol production (Sansonetti et al., 2009). Crude whey was also tested by Zafar and Owais (2006), but lower productivity of $0.1 \mathrm{~g} / \mathrm{L} \cdot \mathrm{h}$ was reached (Table 4 ). The same effect was also observed by Zoppellari and Bardi (2013).

Using microbial consortia is becoming more popular due to the higher genetic variability that a group of different species represents. In fact, with the development of metagenomics and bioinformatics approaches, the utilization of a group of microorganisms isolated from a specific environment encompasses an attractive option (De Felice et al., 2012). A microbial consortium of yeast (mainly $K$. marxianus) and bacteria (mainly Streptococcus) that grew on cheese whey was isolated, and it was used in a batch fermentation with crude cheese whey, resulting in $7.60 \% \mathrm{v} / \mathrm{v}$ ethanol, with a productivity of $1.25 \mathrm{~g} / \mathrm{L} \cdot \mathrm{h}$ (Table 4) (De Felice et al., 2012).

Some efforts were also made to co-produce different value-added products beyond ethanol to increase process economics efficiency (Andrade et al., 2017; You et al., 2017; Sampaio et al., 2019). For example, the $K$. lactis strain B10, isolated from Canastra cheese, was reported to co- 
Table 4.

Fermentative parameters for ethanol production from cheese whey by Kluyveromyces species.

\begin{tabular}{|c|c|c|c|c|c|c|c|c|c|}
\hline Yeast & Substrate & 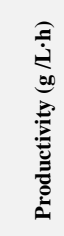 & 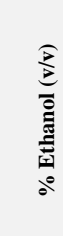 & 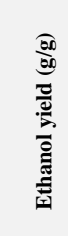 & 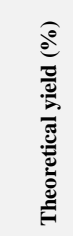 & 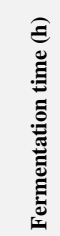 & 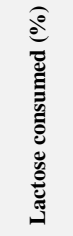 & Fermentation conditions & Reference \\
\hline $\begin{array}{l}\text { Kluyveromyces marxianus } \\
\text { DSM } 5422\end{array}$ & $\begin{array}{l}\text { Cheese whey permeate } \\
(120-170 \mathrm{~g} / \mathrm{L} \text { lactose })\end{array}$ & 1.09 & 6.0 & n.r.* & n.r. & n.r. & n.r. & In a cell immobilized reactor & Díez-Antolínez et al. (2018) \\
\hline K. marxianus DSM 5423 & $\begin{array}{l}\text { Cheese whey permeate } \\
(120-170 \mathrm{~g} / \mathrm{L} \text { lactose })\end{array}$ & 1.23 & 6.0 & 0.45 & 85.3 & 44 & n.r. & $30.3^{\circ} \mathrm{C}, \mathrm{pH} 6.3$ & Díez-Antolínez et al. (2018) \\
\hline K. marxianus NCIM3217 & $\begin{array}{l}\text { Cheese whey powder } \\
(150 \mathrm{~g} / \mathrm{L} \text { lactose })\end{array}$ & 0.61 & 5.54 & 0.29 & n.r. & 72 & n.r. & $\begin{array}{l}\text { Batch fermentation, } \\
\quad 35^{\circ} \mathrm{C}, \mathrm{pH} 4.5\end{array}$ & Das et al. (2016) \\
\hline K. marxianus MTCC 1288 & $\begin{array}{l}\text { Crude cheese whey } \\
\text { ( } 35 \mathrm{~g} / \mathrm{L} \text { lactose })\end{array}$ & 0.1 & 0.26 & n.r. & n.r. & 22 & n.r. & $\begin{array}{c}\text { Batch fermentation, } \\
34^{\circ} \mathrm{C}, \mathrm{pH} 4.5,500 \mathrm{rpm}\end{array}$ & Zafar and Owais (2006) \\
\hline K. marxianus $\mathrm{KD}-15$ & $\begin{array}{l}\text { Mixture of molasses and whey } \\
\text { ( } 200 \mathrm{~g} / \mathrm{L} \text { total sugars) }\end{array}$ & 5.4 & 11.8 & 0.47 & n.r. & n.r. & n.r. & $\begin{array}{l}\text { Batch fermentation, } \\
\qquad 30^{\circ} \mathrm{C}\end{array}$ & Oda and Nakamura (2009) \\
\hline K. marxianus CBS397 & $\begin{array}{l}\text { Ricotta cheese whey } \\
\text { ( } 45 \mathrm{~g} / \mathrm{L} \text { lactose })\end{array}$ & 1.77 & 2.3 & n.r. & 97 & 13 & n.r. & $\begin{array}{l}\text { Anaerobic fermentation }\left(37^{\circ} \mathrm{C} \text {, }\right. \\
\left.200 \mathrm{rpm}, \mathrm{pH} 5 \text { and } 0-0.02 \% \mathrm{O}_{2}\right)\end{array}$ & Sansonetti et al. (2009) \\
\hline $\begin{array}{l}\text { K. marxianus DSMZ } 7239 \\
\text { (immobilized in sodium- } \\
\text { alginate beads) }\end{array}$ & $\begin{array}{l}\text { Raw cheese whey } \\
\text { ( } 45 \mathrm{~g} / \mathrm{L} \text { lactose })\end{array}$ & 4 & n.r. & 0.48 & n.r. & n.r. & n.r. & Continuous fermentation $\left(32^{\circ} \mathrm{C}\right)$ & Christensen et al. (2011) \\
\hline K. marxianus ATCC 8554 & Cheese whey ( $98 \mathrm{~g} / \mathrm{L}$ lactose) & 0.82 & 6.2 & n.r. & 94.6 & 60 & 99.5 & $\begin{array}{l}\text { Batch fermentation with } \\
\text { supplementation } \\
\left(30^{\circ} \mathrm{C}, \mathrm{pH} 4.8\right)\end{array}$ & Koushki et al. (2012) \\
\hline $\begin{array}{l}\text { Microbial consortium (mainly } \\
\text { with } \text { K. marxianus and } \\
\text { Streptococcus) }\end{array}$ & $\begin{array}{l}\text { Crude cheese whey } \\
(50 \mathrm{~g} / \mathrm{L} \text { lactose })\end{array}$ & 1.25 & 7.60 & n.r. & n.r. & 48 & n.r. & $\begin{array}{l}\text { Batch fermentation, hypoxia, } 30 \\
\qquad{ }^{\circ} \mathrm{C}, \mathrm{pH} 4\end{array}$ & De Felice et al. (2012) \\
\hline K. marxianus CBS 712 & $\begin{array}{l}\text { Cheese whey } \\
(42 \mathrm{~g} / \mathrm{L} \text { lactose })\end{array}$ & n.r. & 2.5 & n.r. & n.r. & n.r. & 98.75 & $\begin{array}{l}\text { Semi-continuous fermentation in } \\
\text { packed bed reactor }\end{array}$ & Zoppellari and Bardi (2013) \\
\hline K. marxianus PTCC 5194 & $\begin{array}{l}\text { Deproteinized sweet cheese whey } \\
(50 \mathrm{~g} / \mathrm{L} \text { lactose })\end{array}$ & n.r. & 0.588 & 0.49 & n.r. & n.r. & 91.07 & $\begin{array}{c}\text { Continuous ethanol fermentation } \\
\text { in packed-bed immobilized cell } \\
\text { reactor }\end{array}$ & Roohina et al. (2016) \\
\hline K. marxianus URM 7404 & $\begin{array}{l}\text { Cheese whey } \\
(60 \mathrm{~g} / \mathrm{L} \text { lactose })\end{array}$ & 2.57 & 3.27 & 0.50 & 95.80 & n.r. & n.r. & Scaled up - $36 \mathrm{~L}$ fermentation & Murari et al. (2019) \\
\hline K. marxianus (Kf1) & $\begin{array}{l}\text { Cheese whey powder } \\
\text { ( } 200 \mathrm{~g} / \mathrm{L} \text { lactose) }\end{array}$ & 1.84 & 10.3 & 0.40 & n.r. & 44 & n.r. & $\begin{array}{l}\text { Batch fermentation, } \\
\qquad 30^{\circ} \mathrm{C}\end{array}$ & Dragone et al. (2011) \\
\hline
\end{tabular}

* n.r.: not reported.

produce $19.81 \mathrm{~g} / \mathrm{L}$ ethanol with roughly 39 volatiles aromatic compounds, emphasizing 3-methyl-1-butanol, octanoic acid and ethyl decanoate (Andrade et al., 2017). $\beta$-galactosidase is one of the enzymes produced by Kluyveromyces sp. with high added value. Due to its capacity to hydrolyse lactose, this enzyme can be used to produce galacto-oligosaccharides and lactose-free products required for lactose-intolerance people (Gosling et al., 2010; Oliveira et al., 2011; Sampaio et al., 2019). However, the extraction and purification of $\beta$ galactosidase are expensive and considered a bottleneck for industry applications (Sun et al., 2016). In the past years, a new approach based on cells permeabilization by ethanol has been developed as an alternative to cell disruption and $\beta$-galactosidase extraction (Faria et al., 2013) for possible process integration (Fig. 3).
Genetic engineering strategies have also been applied to Kluyveromyces sp., and multiplex tools like those involving the rescue of selective markers have been developed (Ribeiro et al., 2007). A study reported constructing a mutant strain lacking the KINDII gene that codifies for a dehydrogenase responsible for redox reactions in mitochondria (González-Siso et al., 2015). This deletion promotes a metabolic shift from a respiratory to fermentative metabolism, increasing the fermentation rate (González-Siso et al., 2009). The mutant strain $\triangle K I N D I 1$ produced $16.4 \%$ more ethanol than the parental-wild type strain using cheese whey as a carbon source (González-Siso et al., 2015).

Evolutionary adaptation is an approach of yeast strain improvement that has been exploited during the past years. This strategy is highly used in 
industry to obtain more robust strains with the desired phenotype. Adaptive evolution follows the principle of variation and selection of the more advantageous organism to a specific environmental change. $K$. marxianus MTCC 1389 strain was subjected to high lactose concentrations $(200 \mathrm{~g} / \mathrm{L})$ for $65 \mathrm{~d}$ (Saini et al., 2017a). This evolved strain showed an ethanol titre of $10 \%$ $\mathrm{v} / \mathrm{v}$, a $17.5 \%$ increase compared to the parental strain. Transcriptomic analyses showed that the adaptive evolution resulted in increased expression of GPD1, TPS1, and TPS2 genes. This suggests that the evolved strain accumulates more glycerol and trehalose than the parental strain to improve osmotolerance against lactose stress (Saini et al., 2017b).

Despite the suitable characteristics of Kluyveromyces sp. for ethanol production mentioned above and its aptitude for lactose metabolization, the fermentative potential of this strain is limited when compared to S. cerevisiae, with the latter generally attaining better ethanol titres in the fermentation process (Díez-Antolínez et al., 2018).

\subsection{Exploiting Saccharomyces cerevisiae for cheese whey-to-ethanol valorisation}

$S$. cerevisiae is a GRAS microorganism widely used for bioethanol production (Cunha et al., 2020), being also applied in the production of valueadded chemicals (Baptista et al., 2021). The existing genetic toolbox allied to its high fermentative capacity facilitates the use of this yeast as a microbial cell factory. As mentioned earlier, S. cerevisiae cannot use lactose directly because it lacks the genes required for its transport (lactose permease) and hydrolysis ( $\beta$-galactosidase) (Álvarez-Cao et al., 2020). Still, it can transport galactose (by the permease encoded by the gene GAL2), which is directed to the Leloir pathway inside the cell (Nehlin et al., 1989). Nevertheless, the advantages for biotechnological applications of $S$. cerevisiae justify the attempts to circumvent this hindrance.

One of the most attractive characteristics of $S$. cerevisiae is its high osmotolerance, which enables the fermentation of high lactose concentrations (up to $200 \mathrm{~g} / \mathrm{L}$ ) (Guimarães et al., 2010). Besides this, its ethanol tolerance is also higher, and thus, higher ethanol titres can be reached (Silveira et al., 2020). In fact, some specific industrial strains have been employed in very high gravity ethanol fermentations (Gomes et al., 2021b), reaching ethanol titres higher than $19 \%$ v/v (Pereira et al., 2011a). Taking advantage of the innate capacity of $S$. cerevisiae to produce ethanol, several approaches have been exploited to obtain $S$. cerevisiae strains with the ability to consume lactose. To reach that goal, two main strategies have been addressed: (1) pre-hydrolysis of cheese whey and/or the utilization of $S$. cerevisiae in co-culture with lactose-positive microorganisms; and (2) the introduction of heterologous lactose genes for lactose utilization (Ryan and Walsh, 2016; Álvarez-Cao et al., 2020).

Regarding non-metabolic engineering strategies, the most used approach involves an initial step where lactose is pre-hydrolysed to glucose and galactose (Champagne and Goulet, 1988). The resulting sugar mixture is then used directly by $S$. cerevisiae for ethanol production. However, the presence of glucose hampers galactose metabolization leading to a diauxic growth, which decreases the ethanol yield. Another disadvantage is the high price of $\beta$ galactosidase enzyme, which increases the costs of the process (González-Siso, 1996; Domingues et al., 1999a). To overcome these drawbacks, several approaches have been designed. Bailey et al. (1982) used 2-deoxyglucose, a glucose molecule with an extra alcohol group, as a selection marker. This molecule cannot be hydrolysed, but it can still repress the expression of GAL genes (Sanz et al., 1994). Thus, the mutant cells that can surpass the catabolic repression and consume galactose will survive. The isolated mutant cells were then able to consume glucose and galactose simultaneously, almost with the same effectiveness.

An $S$. cerevisiae mutant able to produce $90 \mathrm{~g} / \mathrm{L}$ ethanol in less than $37 \mathrm{~h}$ was successfully isolated (Table 5) (Bailey et al., 1982). This mutant was used in a continuous fermentation system, reaching ethanol productivity of $13.6 \mathrm{~g} / \mathrm{L} \cdot \mathrm{h}$ (Table 5) (Terrell et al., 1984). The whey permeate was used as a substitute for water in wheat fermentation, and the ethanol yield was not affected, suggesting that cheese whey can be used as water replacement and as a zero-waste solution. In this study, a $\beta$-galactosidase from Aspergillus oryzae was added to hydrolyse lactose (Parashar et al., 2016). Another study reported the utilization of barley-based mash to hydrolyse lactose as an alternative to commercial $\beta$ galactosidase to reduce the overall fermentation costs. The hydrolysis of lactose by mash led to the production of $3.23 \% \mathrm{v} / \mathrm{v}$ of ethanol (Lawton and Alcaine, 2019). The fermentation conditions for pre-hydrolysed cheese whey have also been optimized, using a hydrolysed cheese whey mixture in a bioreactor integrated with a direct contact membrane distillation (Tomaszewska and Białończyk, 2016). The continuous removal of the produced ethanol leads to a 1.9-fold increase in fermentation efficiency. Additionally, it was found that the salt present in the concentrated cheese whey might have decreased the process efficiency (Tomaszewska and Białończyk, 2016).

Cell immobilization techniques were also addressed for $S$. cerevisiae strains. Kokkiligadda et al. (2016) reported the hydrolysis of lactose with $\beta$-galactosidase immobilized in chitosan alongside fermentation by $S$ cerevisiae immobilized in calcium alginate beads, with an ethanol production of $3.6 \% \mathrm{v} / \mathrm{v}$, corresponding to $53.4 \%$ of the maximum theoretical yield (Table 5). Glass raschig rings and alumina beds were reported as the best inorganic supports, that allowed a stable ethanol production for more than $1000 \mathrm{~h}$ operation, yielding $7.6 \% \mathrm{v} / \mathrm{v}$ of ethano with a productivity of $1.09 \mathrm{~g} / \mathrm{L} \cdot \mathrm{h}$ (Table 5) (Díez-Antolínez et al., 2018). On the other hand, gel supports can have stability problems, and organic supports usually require complex derivatization pre-treatments (Lee et al., 2012). Nevertheless, cell immobilization reactors have some disadvantages, such as the reduction of substrate accessibility and alterations in activity due to variations in biocatalyst conformations (Eş et al., 2015).

The utilization of mixed cultures to maximize the potential of different strains and take advantage of the possible synergistic effect has also been gaining interest. Guo et al. (2010) reported cheese whey powder fermentation by a mixed culture of $K$. marxianus TY-3 and S. cerevisiae AY-5, with the production of $4.6 \% \mathrm{v} / \mathrm{v}$ of ethanol, a higher value when compared to a monoculture of $K$. marxianus TY-3 (3.8\% v/v) (Table 5). The utilization of immobilized cells in calcium-alginate beads for cheese whey fermentation was also tested. With a mixed culture and immobilized cells, better ethanol yields were achieved, with $5.3 \% \mathrm{v} / \mathrm{v}$ of ethanol (79.95\% of the maximum theoretical yield) (Guo et al., 2010). An importan factor to point out regarding mixed cultures is the ratio between the microorganisms used. Farkas et al. (2019) tested several ratios of $K$ marxianus Y00963 and S. cerevisiae Levuline FB and an increase from $5.8 \% \mathrm{v} / \mathrm{v}$ to $7.6 \% \mathrm{v} / \mathrm{v}$ of ethanol was achieved with ratios of $1: 1$ and $3: 1$, respectively. Also, when coupled with a fed-batch culture fermentation, an ethanol titre of $10.34 \% \mathrm{v} / \mathrm{v}$ was attained ( $92 \%$ of the theoretical value), one of the highest concentrations described in the literature (Table 5) (Farkas et al., 2019). Interestingly, mixed cultures fermentation led to higher lactose consumption and, consequently, higher ethanol production when compared to monoculture fermentations, reducing substrate inhibition (Farkas et al. 2019). Different strategies could be coupled to increase ethanol productivity. Beniwal et al. (2018) constructed a controlled system for simultaneous lactose hydrolysis and ethanol fermentation. $\beta$-galactosidase enzyme was immobilized in silicon dioxide nanoparticles, while a coculture of $K$. marxianus and $S$. cerevisiae (3:1 ratio) was immobilized in calcium alginate beads in the same fermentation vessel. While part of the lactose is being hydrolysed by $\beta$-galactosidase, another part is already being consumed by K. marxianus. Besides this, galactose is metabolized faster by $K$. marxianus than by $S$. cerevisiae and, therefore, the expected diauxic growth is less prominent. As a result, the fermentation time decreased from 42 to $36 \mathrm{~h}$ and $8.1 \% \mathrm{v} / \mathrm{v}$ of ethanol was obtained with a productivity of 1.78 $\mathrm{g} / \mathrm{L} \cdot \mathrm{h}$ (Table 5) (Beniwal et al., 2018).

As mentioned earlier, several factors could affect fermentation performance, and it can be hard to take them all into account (Diniz et al. 2014). In the past years, numerous mathematical software packages have been employed to correlate all factors and reach a general kinetic model equation to give better fermentation conditions $(\mathrm{pH}$, temperature, substrate concentration) for a specific experiment. One example is the Response Surface Methodology (RSM) that combines mathematical and statistical functions to obtain empirical models for experiments optimization (Uncu and Cekmecelioglu, 2011; Diniz et al., 2014; Myers et al., 2016; Murari et al., 2019). According to the equation proposed by Murari et al. (2019) for K. marxianus URM 7404, the temperature is the factor that most influences productivity, followed by $\mathrm{pH}$ and lactose concentration. For an ethanol yield greater than $90 \%$, the temperature must be between $32.5-35.0^{\circ} \mathrm{C}$, the $\mathrm{pH}$ between 4.8-5.3, and the lactose concentration in the 61-65 g/L range.

Despite all the strategies developed to use wild-type yeast strains for cheese whey fermentation, the construction of a lactose-consuming $S$. cerevisiae is a promising alternative for whey valorisation. In the past thirty years, two different paths were exploited: (1) the construction of 
Table 5.

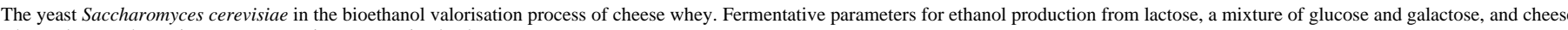
whey substrates by native $S$. cerevisiae in pure or mixed cultures.

\begin{tabular}{|c|c|c|c|c|c|c|c|c|c|c|}
\hline Yeast & Substrate & 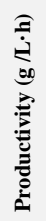 & 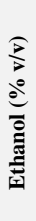 & 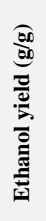 & 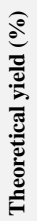 & 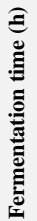 & 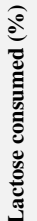 & Fermentation conditions & 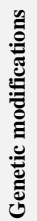 & Reference \\
\hline
\end{tabular}

\begin{tabular}{|c|c|c|c|c|c|c|c|c|c|c|}
\hline $\begin{array}{l}\text { Saccharomyces cerevisiae } \\
\text { (catabolite repression-resistant } \\
\text { mutant) }\end{array}$ & $\begin{array}{l}\text { Rich medium with a mixture of } \\
\text { glucose and galactose } \\
\text { (equivalent to } 200 \mathrm{~g} / \mathrm{L} \text { lactose) }\end{array}$ & 2.3 & 11.4 & n.r.* & n.r. & n.r. & n.r. & Batch fermentation $0.5 \mathrm{~L}$ & $\times$ & Bailey et al. (1982) \\
\hline $\begin{array}{l}\text { S. cerevisiae (catabolite } \\
\text { repression-resistant mutante) }\end{array}$ & $\begin{array}{l}\text { Rich medium with a mixture of } \\
\text { glucose and galactose } \\
\text { (equivalent to } 150 \mathrm{~g} / \mathrm{L} \text { lactose) }\end{array}$ & 13.6 & 8.9 & n.r. & n.r. & n.r. & n.r. & $\begin{array}{l}\text { 6L bioreactor/ continuous } \\
\text { process }\end{array}$ & $\times$ & Terrell et al. (1984) \\
\hline $\begin{array}{l}\text { S. cerevisiae } \\
\text { Ethanol Red }\end{array}$ & $\begin{array}{l}\text { Hydrolised cheese whey } \\
\text { permeate } \\
(120-170 \mathrm{~g} / \mathrm{L} \text { lactose })\end{array}$ & 0.73 & 5.9 & 0.37 & 68.2 & 60 & n.r. & $30.5^{\circ} \mathrm{C}, \mathrm{pH} 5.4$ & $\times$ & $\begin{array}{l}\text { Díez-Antolínez et al. } \\
\text { (2018) }\end{array}$ \\
\hline S. cerevisiae immobilized & $\begin{array}{c}\text { Hydrolysed concentrated } \\
\text { cheese whey ( } 100 \mathrm{~g} / \mathrm{L} \text { lactose })\end{array}$ & n.r. & 3.6 & n.r. & 53.4 & n.r. & n.r. & $\begin{array}{l}\text { S. cerevisiae immobilized } \\
\text { in calcium alginate }\end{array}$ & $\times$ & $\begin{array}{l}\text { Kokkiligadda et al. } \\
\text { (2016) }\end{array}$ \\
\hline $\begin{array}{l}\text { Mixed culture (Kluyveromyces } \\
\text { marxianus TY-3 and } S \text {. } \\
\text { cerevisiae AY-5) with cells } \\
\text { immobilized }\end{array}$ & $\begin{array}{l}\text { Cheese whey powder } \\
\text { (100 g/L lactose })\end{array}$ & 0.88 & 5.30 & 0.43 & 79.95 & 48 & n.r. & $\begin{array}{c}\text { Immobilized cell } \\
\text { concentration of } 22.1 \mathrm{mg} / \mathrm{g} \\
\text { bead }\end{array}$ & $\times$ & Guo et al. (2010) \\
\hline $\begin{array}{l}\text { Mixed culture (K. marxianus } \\
\text { UFLA KF22 and } S \text {. cerevisiae } \\
\text { UFLA KFG33) }\end{array}$ & $\begin{array}{l}\text { Deproteinized cheese whey (46 } \\
\text { g/L lactose) }\end{array}$ & 0.22 & 2.03 & n.r. & n.r. & 72 & n.r. & $28^{\circ} \mathrm{C}$ and $100 \mathrm{rpm}$ shaking & $\times$ & $\begin{array}{l}\text { Magalhães-Guedes et } \\
\text { al. (2013) }\end{array}$ \\
\hline $\begin{array}{l}\text { Mixed culture ( } K \text {. marxianus } \\
\text { MTCC } 4136 \text { and } S \text {. cerevisiae } \\
\text { MTCC } 170) \text { with cells } \\
\text { immobilized }\end{array}$ & $\begin{array}{l}\text { Deproteinized cheese whey } \\
\quad(150 \mathrm{~g} / \mathrm{L} \text { lactose })\end{array}$ & 1.78 & 8.10 & 0.42 & n.r. & 36 & n.r. & $\begin{array}{l}\text { Lactose hydrolysis and } \\
\text { ethanol fermentation } \\
\text { simultaneously } \\
\text { (cells immobilized in } \\
\text { calcium alginate and } \\
\beta \text {-galactosidase } \\
\text { immobilized in silicon } \\
\text { dioxide nanoparticles). } K \text {. } \\
\text { marxianus and } S \text {. } \\
\text { cerevisiae ratio of } 3: 1\end{array}$ & $\times$ & Beniwal et al. (2018) \\
\hline $\begin{array}{l}\text { Mixed culture ( } \text { K. marxianus } \\
\text { Y00693 and } S . \text { cerevisiae } \\
\text { Levuline FB) }\end{array}$ & $\begin{array}{l}\text { Cheese whey powder } \\
\text { (150 g/L lactose) }\end{array}$ & n.r. & 10.34 & n.r. & 92 & n.r. & 92 & Fed-batch fermentation & $\times$ & Farkas et al. (2019) \\
\hline
\end{tabular}

*n.r.: not reported.

recombinant $S$. cerevisiae strains able to produce and secret $\beta$-galactosidase to the external medium; and (2) the construction of recombinant $S$. cerevisiae strains for lactose assimilation and further fermentation (Fig. 4). In the first approach, the production of an extracellular $\beta$-galactosidase enables its recovery from the broth after fermentation, facilitating the downstream processing. Due to the high complexity and cost of this hydrolase production, coupling its production with ethanol fermentation constitutes an advantage (Becerra et al., 2001a). Several organisms can produce $\beta$-galactosidases, including bacteria, yeast, and fungi (Oliveira et al., 2011; Saqib et al., 2017). $\beta$-galactosidase from the filamentous fungus Aspergillus niger is naturally secreted to the extracellular media and is particularly interesting for whey hydrolysis due to its high activity at acidic $\mathrm{pH}$ optimum and high temperatures $\left(40-65^{\circ} \mathrm{C}\right)$, minimizing the risk of contamination (Domingues et al., 2000a). Our group constructed a flocculant $S$. cerevisiae strain able to secret $\beta$ galactosidase of $A$. niger by the expression of lacA gene, using an episomal plasmid (Domingues et al., 2000b, 2002). Due to the genetic instability of plasmid-based systems, multiple copies of lacA were integrated into the genome (Oliveira et al., 2007). Both systems were able to effectively produce the $\beta$-galactosidase enzyme from lactose in batch and continuous fermentation while simultaneously co-producing ethanol (Table 5) (Domingues et al., 2002; Domingues et al., 2005; Oliveira et al., 2017). Also, a secretion pathway is always an attractive method for heterologous protein production (Becerra et al., 2001b) as it simplifies protein recovery and purification.

Another approach encompasses the expression of the lac $Z$ gene coding for an Escherichia coli $\beta$-galactosidase, with a signal sequence to direct to the membrane. However, this is not straightforward, and several tags were tested without success (Venturini et al., 1997). The high molecular weight of $\beta$-galactosidase and the oligomeric nature of this enzyme are hindrances to this goal (Becerra et al., 2001b). The best results were obtained with the membrane protein GgpI (glycosylphosphatidylinositol-containing protein) (Pignatelli et al., 1998). In another study, Porro et al. (1992) proposed the expression of $\beta$-galactosidase from $E$. coli under the control of the upstream activating sequence of GAL genes. The GAL4 activator gene induced cell lysis and release of $\beta$-galactosidase to the extracellular medium. The lysis phenomenon was correlated with high levels of Gal4p, which leads to a loss of plasma membrane integrity. Ethanol was then produced with low productivity, $0.1-0.2 \mathrm{~g} / \mathrm{L} \cdot \mathrm{h}, 73-84 \%$ of the maximum theoretical yield (Porro et al., 1992). The main disadvantage of using $\beta$-galactosidase 


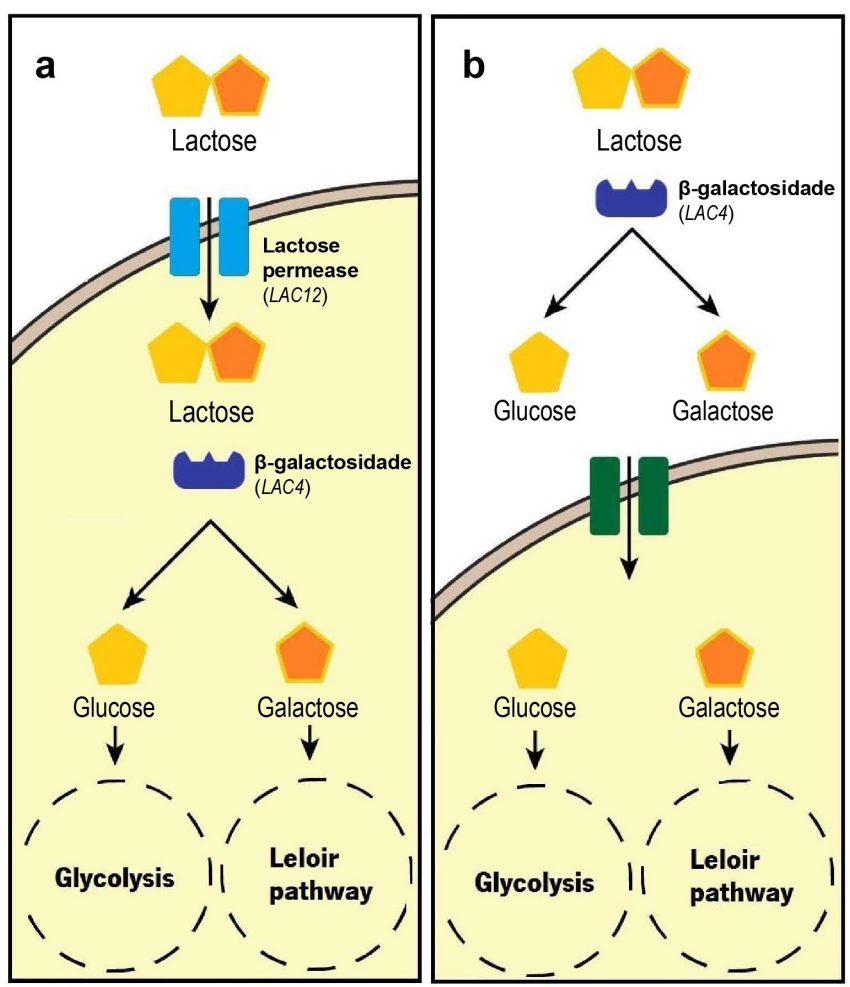

Fig. 4. Lactose consuming pathways by Saccharomyces cerevisiae based on genetic engineering techniques. a) Construction of a lactose-consuming strain $\left(\mathrm{Lac}^{+}\right)$, where the genes responsible for lactose metabolization, LAC4 and LAC12, were introduced in S. cerevisiae. Thus, lactose is transported into the cells, where it is metabolized into the monomers, glucose and galactose. b) A heterologous $\beta$-galactosidase produced by $S$. cerevisiae is secreted to the external medium, where it hydrolyses lactose into glucose and galactose. The simple sugars are then transported into the cells and metabolized. Although glucose is directed to glycolysis, galactose is forwarded to the Leloir pathway.

secretion strategies is the catabolite repression effect that may lead to an undesirable diauxic growth (Guimarães et al., 2010). Interestingly, transformant cells did not show the expected diauxic growth. Gal4p is a regulatory protein related to glucose-repression genes of GAL genes, which could explain the phenomenon. High levels of Gal4p inhibit the repression effect and, therefore, cells consume galactose and glucose simultaneously (Porro et al., 1992).

The control of $\beta$-galactosidase release was also evaluated with the construction of thermosensitive autolytic mutants and cells permeabilization with chemicals agents, such as toluene or ethanol (Compagno et al., 1993; Becerra et al., 2004). The expression of the LAC4 gene from K. lactis, using a secretory plasmid, was also performed, and all the mutants were able to grow in lactose (Becerra, et al., 2001a). A hybrid protein between $\beta$-galactosidase from $K$. lactis and A. niger was also constructed to increase the secretion capacity. In this study, the domains of $\beta$-galactosidase that play an important role in the secretion process were determined. A higher yield in protein release and a better affinity for lactose was shown for the new hybrid protein (Rodríguez et al., 2006).

A different approach to combine the best characteristics of Kluyveromyces sp. and $S$. cerevisiae resorts to protoplast fusion, a widely used technique for genetic improvement in industrial yeasts (Guo et al., 2012). In this procedure, cell walls are removed with specific enzymes to obtain a hybrid organism that shares organelle, cytoplasm, and genetic material (Wolf et al., 1996). The possibility to create a hybrid yeast strain that includes a lactose-consuming $\mathrm{Lac}^{+}$ yeast with high ethanol tolerance has been pointed out, and several insights are found in the literature. In a first attempt, a hybrid between S. cerevisiae and $K$. lactis was obtained. This strain was able to produce higher ethanol concentrations $(5.5 \% \mathrm{v} / \mathrm{v})$ compared to the parental strain $(4.1 \% \mathrm{v} / \mathrm{v})($ Taya et al., 1984). Later, Farahnak et al. (1986) constructed a hybrid between $S$. cerevisiae and $K$. marxianus that was able to produce $30 \%$ more ethanol than the parental strain K. marxianus strain, with ethanol titre of $13 \% \mathrm{v} / \mathrm{v}$ and productivity of $1.3 \mathrm{~g} / \mathrm{L} \cdot \mathrm{h}$ (Table 6) (Farahnak et al., 1986). Ryu et al. (1991) obtained fusants between these strains with a productivity of $2.42 \mathrm{~g} / \mathrm{L} \cdot \mathrm{h}$ and explained the rationale behind ethanol tolerance (Table 6). Alcohols are soluble in lipids, and so they can penetrate the plasmatic membrane and alter membrane fluidity. As a consequence, the transport of nutrients across the membrane will be inhibited. S. cerevisiae, as well as the fusant obtained, has higher content in unsaturated fatty acids, particularly linoleic acid, which provide a higher ethanol tolerance, compared to others yeast species Later, another hybrid strain derived from $K$. marxianus and $S$. cerevisiae was obtained, and a $3.8 \% \mathrm{v} / \mathrm{v}$ ethanol titre was reported by fermentation of cheese whey powder (Guo et al., 2012).

Another strategy consists of introducing heterologous genes for lactose assimilation to the cytoplasm and its hydrolysis inside the cells (Fig. 4b) The first attempt to express K. lactis LAC4 and LAC12 genes was reported by Sreekrishna and Dicksont (1985). The genome region of $K$. lactis, which includes both $L A C 4$ and $L A C 12$ genes, as well as an intergenic region codifying for the natural promoters of $K$. lactis, was expressed in $S$ cerevisiae. The resulting transformants grew very slow in lactose medium, with a doubling time of 6-7 h. Moreover, the authors also reported that the transformants integrated more than 15 tandem copies of the recombinant vector in a chromosome (Sreekrishna and Dickson, 1985). A second attempt was tried by Jeong et al. (1991), where a yeast integrative vector was used instead of a usual cloning vector. Nevertheless, the isolated transformants showed slow growth rates in the lactose medium.

Later, Rubio-Texeira et al. (1998) attempted to replace the native promoters of $L A C 4$ and $L A C 12$ genes with $C Y C$-GAL promoters (a galactose-inducible hybrid promoter). Also, the recombinant DNA fragment was targeted for a ribosomal DNA region (RDN1 locus). After different selection methodologies, a fast-growing $\mathrm{Lac}^{+}$diploid $S$. cerevisiae strain was obtained. Still, in lactose medium, the obtained strain exhibited a respiro-fermentative metabolism, with high biomass yield and low ethanol titres, similar to K. marxianus (Table 6) (Rubio-Texeira et al., 1998).

Our research group constructed a flocculent $S$. cerevisiae $\mathrm{Lac}^{+}$strain (T1) based on the same plasmid (pKR1B-LAC4-1) used by Sreekrishna and Dickson (1985) (Domingues et al., 1999a). This strain was able to consume $10 \mathrm{~g} / \mathrm{L}$ lactose, independently of the initial lactose concentration, and produced 2.0\% v/v of ethanol (Table 6) (Domingues et al., 1999a). After a physiological adaptation process, the growth rate increased, and the lactose metabolization ability improved - this strain consumed $50 \mathrm{~g} / \mathrm{L}$ lactose in 40 $\mathrm{h}$ and produced $16 \mathrm{~g} / \mathrm{L}$ of ethanol (Domingues et al., 1999b). In continuous operating airlift bioreactor experiments, it was possible to reach a productivity of $10-11 \mathrm{~g} / \mathrm{L} \cdot \mathrm{h}$, opening new perspectives in cheese whey valorisation (Table 6) (Domingues et al., 1999b and 2001). However, the constructed strain lost its lactose metabolization capacity upon conservation. Thus, a long-term evolutionary engineering experiment was carried out, and a stable strain able to be frosted and defrosted without losing its lactose-metabolizing capacity, designated T1E, was isolated (Guimarães et al., 2008a). It was observed that the T1E strain had a deletion of $1593 \mathrm{bp}$ in the intergenic region between LAC4 and LAC12 genes. Also, the evolved strain had a reduction of approximately 10 -fold in the number of copies of the recombinant plasmid, about 10 -fold, compared to the $\mathrm{T} 1$ strain (Guimarães et al., 2008b). A transcriptome analysis identified at least 173 genes with differential expression levels, mostly related to RNAmediated transposition, DNA repair, and recombination mechanisms (Guimarães et al., 2008b). These results suggest that the loss of the intergenic-region fragment leads to an alteration of the promoter structure that will, therefore, contribute to a better inducible lactose-promoter. This effect, accompanied by a lower plasmid copy number, leads to an improved overall phenotype in terms of lactose consumption (Guimarães et al., 2008b).

A multi-route non-structural kinetic model for the interpretation of ethanol fermentation of lactose using this recombinant strain was also developed (Juraščík et al., 2006). Batch fermentations with high-lactose concentrations were performed with T1E strain, attaining $8 \% \mathrm{v} / \mathrm{v}$ of ethanol from $150 \mathrm{~g} / \mathrm{L}$ lactose in a synthetic medium with a productivity of 1.5-2.0 $\mathrm{g} / \mathrm{L} \cdot \mathrm{h}$. When cheese whey was used as carbon source, $7 \% \mathrm{v} / \mathrm{v}$ ethanol titre was reached but the fermentation was slower (Table 6) (Guimarães et al., $2008 \mathrm{~b}$ and c; Silva et al., 2010). Thus, the T1E strain was not just able to 
Table 6 .

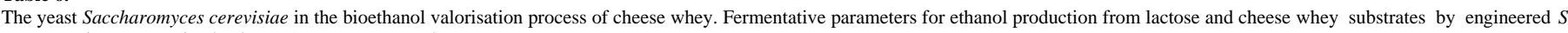
cerevisiae in pure or mixed cultures (n.r. - not reported)

\begin{tabular}{|c|c|c|c|c|c|c|c|c|c|c|}
\hline Yeast & Substrate & 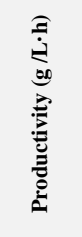 & 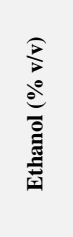 & 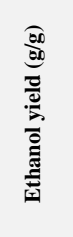 & 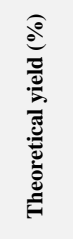 & 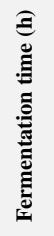 & 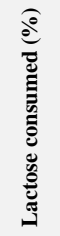 & Fermentation conditions & 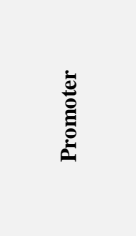 & Reference \\
\hline $\begin{array}{l}\text { S. cerevisiae STX } 23-5 \mathrm{~B}-\mathrm{K} \text {. } \\
\text { marxianus } 55-55 \text { hybrid } \\
\text { (Protoplast fusion) }\end{array}$ & $\begin{array}{c}\text { Lactose } \\
\text { (until } 70 \mathrm{~g} / \mathrm{L} \text { ) }\end{array}$ & 1.3 & 13.00 & n.r.* & n.r. & n.r. & n.r. & $\begin{array}{l}\text { 0.3 L Bioreactor/ Fed-batch } \\
\text { fermentation }\end{array}$ & n.r. & Farahnak et al. (1986) \\
\hline $\begin{array}{l}\text { S. cerevisiae STV } 89-K \text {. } \\
\text { marxianus CBS } 397 \text { hybrid } \\
\text { (Protoplast fusion) }\end{array}$ & Lactose $(20 \mathrm{~g} / \mathrm{L})$ & 2.42 & 10.44 & 0.459 & n.r. & n.r. & n.r. & Batch fermentation & n.r. & Ryu et al. (1991) \\
\hline $\begin{array}{l}\text { S. cerevisiae secreting } A \text {. niger } \beta \text { - } \\
\text { galactosidase } \\
\text { (NCYC } 869-\mathrm{A} 3 \text { ) }\end{array}$ & $\begin{array}{l}\text { Semi-synthetic lactose (50 } \\
\text { g/L) medium }\end{array}$ & 1 & 3.17 & n.r. & 80 & 25 & 90 & $\begin{array}{l}\text { 2L Bioreactor/ Batch } \\
\text { culture }\end{array}$ & $A D H 1$ & $\begin{array}{l}\text { Domingues. et al. } \\
(2002)\end{array}$ \\
\hline $\begin{array}{l}\text { S. cerevisiae secreting } A \text {. niger } \beta \text { - } \\
\text { galactosidase } \\
\text { (NCYC869-A3) }\end{array}$ & $\begin{array}{l}\text { Semi-synthetic lactose (50 } \\
\text { g/L) medium }\end{array}$ & 9 & 2.5 & n.r. & $74-83$ & n.r. & 90 & $\begin{array}{l}6.5 \mathrm{~L} \text { airlift continuous } \\
\text { bioreactor }\end{array}$ & $A D H 1$ & $\begin{array}{l}\text { Domingues et al. } \\
(2005)^{* *}\end{array}$ \\
\hline $\begin{array}{l}\text { S. cerevisiae (X4004 and } \\
\text { MVY4935) expressing E. coli } \beta \text { - } \\
\text { galactosidase and Gal4p }\end{array}$ & $\begin{array}{l}\text { Lactose }(20-60 \mathrm{~g} / \mathrm{L}) \text { and } \\
\text { nitrogen supplementation }\end{array}$ & $0.1-0.2$ & 2.3 & n.r. & $73-84$ & n.r. & 97 & Batch culture & $\begin{array}{c}U A S_{G A L} / \\
C Y C 1\end{array}$ & Porro et al. (1992) \\
\hline $\begin{array}{l}\text { S. cerevisiae expressing LAC4 } \\
\text { and LAC12 (MRY286) }\end{array}$ & $\begin{array}{l}\text { Synthetic lactose }(22 \mathrm{~g} / \mathrm{L}) \\
\text { medium }\end{array}$ & 0.3 & 0.5 & n.r. & 34 & n.r. & 100 & $\begin{array}{l}\text { 2L Bioreactor/ Batch } \\
\text { culture }\end{array}$ & $C Y C-G A L$ & $\begin{array}{l}\text { Rubio-Texeira et al. } \\
\text { (1998) }\end{array}$ \\
\hline $\begin{array}{l}\text { S. cerevisiae expressing LAC4 } \\
\text { and LAC12 (NYCY869-A3) }\end{array}$ & $\begin{array}{l}\text { Semi-synthetic lactose ( } 50 \\
\text { g/L) medium }\end{array}$ & 0.45 & 2.0 & n.r. & n.r. & n.r. & n.r. & Shake flasks & $\begin{array}{l}\text { Natural } \\
\text { promoters of } \\
\text { LAC4 and } \\
\text { LAC12 }\end{array}$ & $\begin{array}{l}\text { Domingues et al. } \\
\text { (1999b) }\end{array}$ \\
\hline $\begin{array}{l}\text { S. cerevisiae expressing LAC4 } \\
\text { and LAC12 (NYCY869-A3) }\end{array}$ & $\begin{array}{l}\text { Cheese whey permeate } \\
\qquad(50 \mathrm{~g} / \mathrm{L})\end{array}$ & 11 & 2.5 & n.r. & 75 & n.r. & 94 & $\begin{array}{l}6 \mathrm{~L} \text { air-lift bioreactor/ } \\
\text { continuous }\end{array}$ & $\begin{array}{l}\text { Natural } \\
\text { promoters of } \\
\text { LAC4 and } \\
\text { LAC12 }\end{array}$ & $\begin{array}{l}\text { Domingues et al. } \\
\text { (2001) }\end{array}$ \\
\hline $\begin{array}{l}\text { S. cerevisiae expressing LAC4 } \\
\text { and LAC12 (NYCY869-A3) }\end{array}$ & $\begin{array}{l}\text { Concentrated whey } \\
\text { powder solution } \\
(150 \mathrm{~g} / \mathrm{L} \text { lactose })\end{array}$ & 0.46 & 7 & n.r. & 70 & n.r. & 98 & Batch fermentation & $\begin{array}{l}\text { Natural } \\
\text { promoters of } \\
\text { LAC4 and } \\
\text { LAC12 }\end{array}$ & $\begin{array}{l}\text { Guimarães et al. } \\
(2008 \mathrm{c})\end{array}$ \\
\hline $\begin{array}{l}\text { S. cerevisiae expressing LAC4 } \\
\text { and LAC12 (NYCY869-A3) }\end{array}$ & $\begin{array}{l}\text { Synthetic lactose medium } \\
\quad(150 \mathrm{~g} / \mathrm{L} \text { lactose })\end{array}$ & $1.5-2.0$ & 8 & n.r. & $78-84$ & n.r. & 98 & Batch fermentation & $\begin{array}{l}\text { Natural } \\
\text { promoters of } \\
\text { LAC4 and } \\
\text { LAC12 }\end{array}$ & $\begin{array}{l}\text { Guimarães et al. } \\
(2008 \mathrm{c})\end{array}$ \\
\hline $\begin{array}{l}\text { S. cerevisiae expressing LAC4 } \\
\text { and LAC12 (AY-51024A) }\end{array}$ & $\begin{array}{l}\text { Cheese whey permeate } \\
\text { concentrated by } 3 \text { folds } \\
\text { ( } 150 \mathrm{~g} / \mathrm{L} \text { lactose })\end{array}$ & 0.21 & 4.5 & n.r. & 70.2 & 120 & 65.7 & $\begin{array}{l}\text { Anaerobic shake-flask } \\
\text { fermentation }\end{array}$ & $P G K$ & Zou et al. (2013) \\
\hline $\begin{array}{l}\text { S. cerevisiae expressing LAC4 } \\
\text { and LAC12 (AY-51024M) }\end{array}$ & $\begin{array}{l}\text { Cheese whey permeate } \\
\text { concentrated by } 3 \text { folds } \\
\text { (150 g/L lactose })\end{array}$ & 0.53 & 8.0 & n.r. & 78.4 & 120 & n.r. & $\begin{array}{l}\text { Anaerobic shake-flask } \\
\text { fermentation }\end{array}$ & $P G K$ & Zou et al. (2013) \\
\hline $\begin{array}{l}\text { S. cerevisiae expressing CDT-1 } \\
\text { and GH1-1 (EJ2e8) }\end{array}$ & $\begin{array}{l}\text { Cheese whey permeate } \\
\text { concentrated by } 3 \text { folds } \\
\text { (150 g/L lactose })\end{array}$ & 1.02 & 6.2 & 0.336 & n.r. & 48 & 100 & $\begin{array}{l}\text { Oxygen-limited shake-flask } \\
\text { fermentation }\end{array}$ & $\begin{array}{c}\text { Natural } \\
\text { promoters of } \\
C D T-1 \text { and } \\
\text { GHI-1 }\end{array}$ & Liu et al. (2016) \\
\hline $\begin{array}{l}\text { S. cerevisiae expressing LAC4 } \\
\text { and LAC12 (AY-GM) }\end{array}$ & $\begin{array}{l}\text { Cheese whey permeate } \\
\text { solution (100 g/L lactose) }\end{array}$ & 0.742 & 4.45 & n.r. & 84.0 & 60 & 100 & $\begin{array}{l}\text { 5L Bioreactor/ Batch } \\
\text { culture }\end{array}$ & $P G K$ & Zou et al. (2021) \\
\hline
\end{tabular}

*n.r.: not reported.

*** Coupled with ethanol production. 
maintain the phenotype but also to efficiently ferment lactose from cheese whey with high ethanol titres (Guimarães et al., 2008c). Both T1 and T1E strains are flocculating yeast strains, a characteristic that takes several advantages for industrial applications (Domingues et al., 2000b).

Zou et al. (2013) constructed two lactose-consuming S. cerevisiae strains based on the deletion of specific genes that could improve ethanol production. One of them, S. cerevisiae AY-51024A, has the LAC4 and LAC12 genes to enable lactose consumption introduced in the region of $A T H 1$ and $N T H 1$ genes, leading to the knockout of those genes. The accumulation of trehalose in the cells is associated with high-stress tolerance, and $S$. cerevisiae has two enzymes that hydrolyse this molecule - a neutral cytosolic trehalase (codified by NTHI gene) and an acidic vacuolar trehalase (encoded by ATH1 gene). Thus, the deletion of $A T H 1$ and $N T H 1$ will increase intracellular trehalose levels that could, in turn, increase ethanol titre. The other strain, S. cerevisiae AY$51024 \mathrm{M}$, is based on the same lactose consumption genes mentioned above allied to the deletion of MIG1 and NTH1. MIGl gene codifies for Mig1 protein that has an important role in the glucose repression effect. This protein is responsible for directing a complex protein to the consensus motif of the GALA promoter that inhibits GAL4 gene expression. GALA codifies for Gal4, a transcriptional activator protein of GAL genes. Consequently, GAL genes will not be expressed, and galactose will not be consumed. With Mig1 deletion, this repression effect is abolished, and glucose and galactose can be consumed simultaneously. An anaerobic shake flask fermentation was performed with both strains using cheese whey (with $150 \mathrm{~g} / \mathrm{L}$ lactose) as a carbon source. AY$51024 \mathrm{M}$ strain produced $8.0 \% \mathrm{v} / \mathrm{v}$ of ethanol in $120 \mathrm{~h}$, representing productivity of $0.53 \mathrm{~g} / \mathrm{L} \cdot \mathrm{h}$. On the other hand, AY-51024A produced $4.5 \% \mathrm{v} / \mathrm{v}$ of ethanol at the same fermentation time, but only $63.7 \%$ of initial lactose was consumed (Table 6) (Zou et al., 2013). Thus, it suggests that catabolic repression has a more powerful inhibitory effect than osmotolerance. In a subsequent study, the authors uncoupled glucose and galactose metabolism in S. cerevisiae by deletion of GAL8O and MGII again coupled to LAC4 and LAC12 expression. This resulted in the loss of diauxic growth and glucose repression, consequently leading to galactose consumption at higher rates, ultimately yielding higher ethanol titres. Likewise, lactose consumption and ethanol productivity rates also increased compared to AY-51024M when cultivated in cheese whey permeate powder solution (Zou et al., 2021).

Liu et al. (2016) reported that an engineered S. cerevisiae strain to consume cellobiose is also able to ferment lactose. This means that the cellobiose transporter CDT-1 can transport lactose and $\beta$-glucosidase can act as $\beta$ galactosidase and ferment lactose. The lactose fermentation ability was improved by artificial evolution, and an improved strain (EJ2e8), with a high copy number of $C D T-1$ and $G H 1-1$ genes, was obtained. This strain could ferment lactose in a batch fermentation from cheese whey powder $(150 \mathrm{~g} / \mathrm{L}$ lactose). All lactose was consumed in $48 \mathrm{~h}$, and $6.2 \% \mathrm{v} / \mathrm{v}$ of ethanol was produced (Table 6) (Liu et al., 2016). This study opened a new window of opportunities in terms of lactose-consuming $S$. cerevisiae strains. Genetic constructions beyond LAC4 and LAC12 genes may be explored for the attainment of $\mathrm{Lac}^{+} S$. cerevisiae strains. Also, the promoter influence should be evaluated, as it may play a central role in the activity of both the permease and $\beta$-galactosidase. While some studies successfully used the natural promoters of LAC4 and LAC12 (Sreekrishna and Dickson, 1985; Domingues et al., 1999b and 2001; Guimarães et al., 2008c), the use of constitutive promoters of $S$. cerevisiae like ADH1 (Domingues et al., 2002 and 2005) or PGK (Zou et al., 2013 and 2021) has also been shown to be an effective strategy for lactose metabolization. Further investigation on the influence of different constitutive promoters and the optimum balance between the activity of the permease and $\beta$-galactosidase can also be valuable for improved lactose consumption.

Overall, the yeast $S$. cerevisiae shows itself as a suitable host for engineering lactose metabolizing traits. Some of the recombinant strains described so far are effective in converting lactose to ethanol, completely metabolizing the lactose available and reaching ethanol titres that can be economically competitive.

3.3. Incorporation of cheese-whey into lignocellulose biomass-to-ethanol processes

Lignocellulose-to-ethanol processes hold the promise of cleaner energy sources as lignocellulosic materials (LCMs) comprise complex sugars that can be converted by microorganisms to ethanol. LCMs are abundant, cheap, and do not compete with food crops. Still, the ethanol titres achieved in second- generation ethanol processes are typically below the $4 \%$ threshold commonly associated with economically viable processes (Gomes et al., 2021a). To increase ethanol titres and thus improve the process economic feasibility, increased overall solid loadings may be used with significant constraints on solid viscosity and mass transfer. An interesting alternative could be the use of low-cost sugar sources that could be economically viable on an industrial scale (Gomes et al., 2021a). Cheese whey and whey permeate are found among the most significant (and unavoidable) industrial waste streams and are constituted by a considerable amount of sugar (approx. $50 \mathrm{~g} / \mathrm{L}$ lactose). Besides, due to its recognised nutritional value, cheese whey has been applied as a supplement in yeast fermentation (Kelbert et al., 2015). Also, the improvement in yeast cell metabolism derived from nutritional supplementation in lignocellulose-to-ethanol processes has been demonstrated (Kelbert et al., 2015; van Dijk et al., 2020). Thus, the integration of cheese whey in multi-waste valorisation approaches, in particular, with LCMs as substrate, is a recently explored application where the integration of cheese whey increases the overal concentration of the carbon source, thus increasing ethanol titre with a consequent decrease in distillation costs, besides improving yeast cell metabolism and decreasing water usage. In fact, whey supplementation has been used just for water replacement in wheat straw fermentation (Parashar et al., 2016). Moreover, the mixture of cheese whey powder with Eucalyptus globulus wood was proposed to intensify simultaneous saccharification and fermentation at high solid loadings and high temperature, which boosted ethanol concentration by 1.5 folds compared to the results obtained without cheese whey powder (Cunha et al., 2018). When analysing the economic determinants on the implementation of a Eucalyptus wood biorefinery producing biofuels, energy, and high addedvalue compounds, the supplementation of low-cost cheese whey (Fig. 5) allowed a $52 \%$ increase of ethanol titres, leading to a clear improvement in the process net present value (NPV) from -14.4 to -3.4 million USD (Gomes et al., 2021a).

In addition, strategies used to metabolically engineer $S$. cerevisiae for lactose consumption can also be applied in this regard. In fact, a consolidated bioprocess was developed by cell surface display of cellulolytic enzymes, alongside $\beta$-galactosidase, in engineered thermotolerant industrial $S$. cerevisiae strains. This effort resulted in high ethanol titres (above $50 \mathrm{~g} / \mathrm{L}$ ), enabling simultaneous valorisation of corn cob and cheese whey and reducing costs (Cunha et al., 2021). For these multi-waste valorisation approaches comprising lignocellulosic residues, $S$ cerevisiae presents additional benefits against other yeast, such as the tolerance to the typical lignocellulosic inhibitors (Cunha et al., 2019), in particular, for some industrial isolated strains (Costa et al., 2017) besides the identification of specific tolerance molecular determinants (Pereira et al., 2011b). Still, Kluyveromyces sp. that naturally metabolizes lactose besides xylose, a relevant pentose in lignocellulose composition, are starting to be explored for lignocellulosic conversion processes and could be directly integrated into these multi-waste valorisation processes (Ferreira et al., 2015)

\section{Conclusions and future perspectives}

Cheese whey valorisation can substantially reduce the disposal problem, providing significant environmental benefits. According to the current environmental concerns, implementing circular bioeconomy systems to reduce by-products disposal is mandatory. Nevertheless, cheese whey has been recognized as a resource to be exploited rather than a waste requiring disposal. We can summarize cheese whey valorisation in two central branches. The first mainly involves physical processing to transform cheese whey into functional and nutritional fractions (WPC, WPI, WPH, and individual proteins). These fractions find several applications in the food industry (as nutritional supplementation, beverages, and as food ingredients) and also in the cosmetic and pharmaceutical industries. In the second valorisation route, lactose-rich cheese whey or cheese whey permeate can be used as a substrate in fermentation processes. The potential of natural lactose-consuming yeasts, especially Kluyveromyces sp., has been fully exploited, and many interesting value-added products have been produced, like citric acid, glycerol, enzymes like $\beta$-galactosidase, organic acids, and ethanol, as the prevalent product. Nonetheless, despite the advances made in the last years, $S$. cerevisiae strains constitute the best 


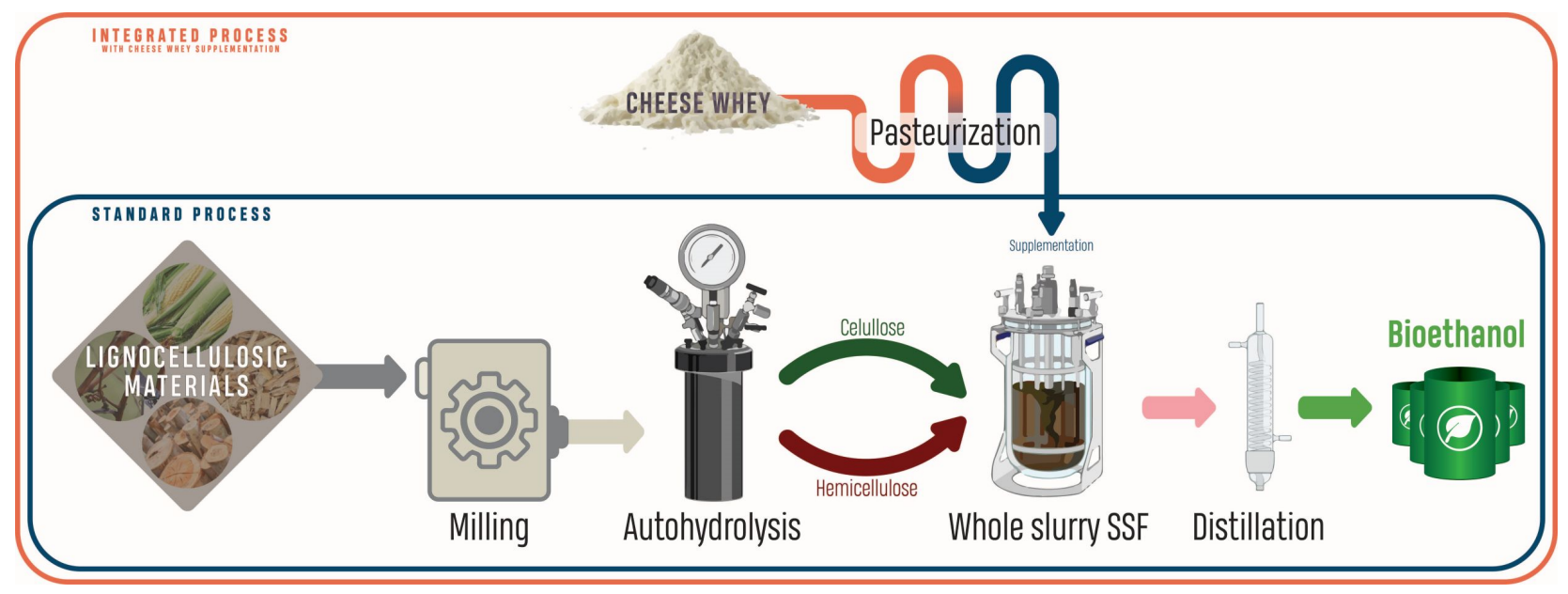

Fig. 5. Schematic presentation of a lignocellulose-to-bioethanol process with integration of cheese whey supplementation.

choice for ethanol production. Its fermentative capacity allied to its high tolerance to osmotic stress and harsh industrial conditions has triggered the development of $S$. cerevisiae as a chassis microorganism for metabolic engineering aiming at the valorisation of cheese whey. Besides, due to its robustness and tolerance to fermentation inhibitors, a future central role is foreseen for S. cerevisiae in multi-waste valorisation approaches, where LCMs and whey residues may be combined to increase the overall concentration of the carbon source. This approach leads to higher ethanol titres, diminishing the distillation costs and thus, will contribute to fulfilling the worldwide needs for biofuel ethanol. Furthermore, the biorefinery concept, in which renewable carbon sources are converted into energy and multiple added-value products, is key to achieving a sustainable economy. An industrial whey to ethanol plant comprising the production of other value-added products, such as $\beta$ galactosidase that could be used in situ in the dairy industry, could represent an economic incentive to implement this biorefinery concept. Still, economic and sustainability analyses are needed for determining the best option. In any case, cheese whey valorisation has the potential to comprise multi-valorisation strategies that confer flexibility to the process, enabling it to be marketresponsive, a key aspect of the fast-changing times we live in.

\section{Acknowledgements}

This work was supported by the Portuguese Foundation for Science and Technology (FCT) under the scope of the strategic funding of UIDB/04469/2020; the Ph.D. grants SFRH/BD/130739/2017 and SFRH/BD/132717/2017 to CEC and SLB, respectively.

\section{References}

[1] Abdel-Banat, B.M.A., Hoshida, H., Ano, A., Nonklang, S., Akada, R., 2010. High-temperature fermentation: how can processes for ethanol production at high temperatures become superior to the traditional process using mesophilic yeast?. Appl. Microbiol. Biotechnol. 85(4), 861-867.

[2] Abou-Zeid, A.Z.A., Baghlaf, A.O., Khan, J.A., Makhashin, S.S., 1983. Utilization of date seeds and cheese whey in production of citric acid by Candida lipolytica. Agric. Wastes. 8(3), 131-142.

[3] Addai, F.P., Lin, F., Wang, T., Kosiba, A.A., Sheng, P., Yu, F., Gu, J., Zhou, Y., Shi, H., 2020. Technical integrative approaches to cheese whey valorization towards sustainable environment. Food Funct. 11(10), 8407-8423.

[4] Aguilera, F., Peinado, R.A., Millán, C., Ortega, J.M., Mauricio, J.C., 2006. Relationship between ethanol tolerance, $\mathrm{H}^{+}$-ATPase activity and the lipid composition of the plasma membrane in different wine yeast strains. Int. J. Food Microbiol. 110(1), 34 42.

[5] Álvarez-Cao, M.E., Becerra, M., González-Siso, M.I., 2020 Biovalorization of cheese whey and molasses wastes to galactosidases by recombinant yeasts, in: Biovalorisation of Wastes to Renewable Chemicals and Biofuels. Elsevier, pp. 149-161.

[6] Andrade, R.P., Melo, C.N., Genisheva, Z., Schwan, R.F. Duarte, W.F., 2017. Yeasts from Canastra cheese production process: isolation and evaluation of their potential for cheese whey fermentation. Food Res. Int. 91, 72-79.

[7] Arous, F., Frikha, F., Triantaphyllidou, I.E., Aggelis, G., Nasri, M., Mechichi, T., 2016. Potential utilization of agroindustrial wastewaters for lipid production by the oleaginous yeast Debaryomyces etchellsii. J. Clean. Prod. 133, 899-909.

[8] Arous, F., Atitallah, I. Ben, Nasri, M., Mechichi, T., 2017. A sustainable use of low-cost raw substrates for biodiesel production by the oleaginous yeast Wickerhamomyces anomalus. 3 Biotech, 7(4), pp. 1-10.

[9] Arslan, N.P., Aydogan, M.N., Taskin, M., 2016. Citric acid production from partly deproteinized whey under non-sterile culture conditions using immobilized cells of lactose-positive and cold-adapted Yarrowia lipolytica B9. J. Biotechnol. 231, 32-39.

[10] Asunis, F., De Gioannis, G., Dessì, P., Isipato, M., Lens, P.N., Muntoni, A., Polettini, A., Pomi, R., Rossi, A., Spiga, D., 2020. The dairy biorefinery: integrating treatment processes for cheese whey valorisation. J. Environ. Manage. 276, 111240 .

[11] Audic, J.L., Chaufer, B., Daufin, G., 2003. Non-food applications of milk components and dairy co-products: a review. Le Lait. 83(6), 417-438.

[12] Bailey, R.B., Benitez, T., Woodward, A., 1982. Saccharomyces cerevisiae mutants resistant to catabolite repression: use in cheese whey hydrolysate fermentation. Appl. Environ. Microbiol. 44(3), 631-639.

[13] Balat, M., 2011. Production of bioethanol from lignocellulosic materials via the biochemical pathway: a review. Energy Convers. Manage. 52(2), 858-875.

[14] Bansal, S., Oberoi, H.S., Dhillon, G.S., Patil, R.T., 2008. Production of $\beta$-galactosidase by Kluyveromyces marxianus 
MTCC 1388 using whey and effect of four different methods of enzyme extraction on $\beta$-galactosidase activity. Indian $\mathrm{J}$. Microbiol. 48(3), 337-341.

[15] Baptista, S.L., Costa, C.E., Cunha, J.T., Soares, P.O., Domingues, L., 2021. Metabolic engineering of Saccharomyces cerevisiae for the production of top value chemicals from biorefinery carbohydrates. Biotechnol. Adv. 47, 107697.

[16] Barile, D., Tao, N., Lebrilla, C.B., Coisson, J.D., Arlorio, M., German, J.B., 2009. Permeate from cheese whey ultrafiltration is a source of milk oligosaccharides. Int. Dairy J. 19(9), 524-530.

[17] Becerra, M., Prado, S.D., Cerdán, E., Siso, M.G., 2001a. Heterologous Kluyveromyces lactis $\beta$-galactosidase secretion by Saccharomyces cerevisiae super-secreting mutants. Biotechnol. Lett. 23(1), 33-40.

[18] Becerra, M., Prado, S.D., Siso, M.G., Cerdán, M.E., 2001b. New secretory strategies for Kluyveromyces lactis $\beta$-galactosidase. Protein Eng. 14(5), 379-386.

[19] Becerra, M., Rodríguez-Belmonte, E., Cerdán, M.E., González Siso, M.I.G., 2004. Engineered autolytic yeast strains secreting Kluyveromyces lactis $\beta$-galactosidase for production of heterologous proteins in lactose media. J. Biotechnol. 109(1-2), 131-137.

[20] Beniwal, A., Saini, P., Kokkiligadda, A., Vij, S., 2018. Use of silicon dioxide nanoparticles for $\beta$-galactosidase immobilization and modulated ethanol production by co-immobilized $K$. marxianus and S. cerevisiae in deproteinized cheese whey. LWT. 87, 553-561.

[21] Bosso, A., Setti, A.C.I., Tomal, A.B., Guemra, S., Morioka, L.R.I., Suguimoto, H.H., 2019. Substrate consumption and betagalactosidase production by Saccharomyces fragilis IZ 275 grown in cheese whey as a function of cell growth rate. Biocatal. Agric. Biotechnol. 21, 101335.

[22] Boze, H., Mouhn, G., Galzu, P., 1987. Galactose and Lactose Transport in Kluyveromyces lactis. Folia Microbiol. 32(2), 107.

[23] Brandelli, A., Daroit, D.J., Corrêa, A.P.F., 2015. Whey as a source of peptides with remarkable biological activities. Food Res. Int. 73, 149-161.

[24] Breunig, K.D., Bolotin-Fukuhara, M., Bianchi, M.M., Bourgarel, D.., Falcone, C., Ferrero, I., Frontali, L., Goffrini, P., Krijger, J.J., Mazzoni, C., Milkowski, C., 2000. Regulation of primary carbon metabolism in Kluyveromyces lactis. Enzyme Microb. Technol. 26(9-10), 771-780

[25] Carota, E., Crognale, S., D’Annibale, A., Gallo, A.M., Stazi, S.R., Petruccioli, M., 2017. A sustainable use of Ricotta Cheese Whey for microbial biodiesel production. Sci. Total Environ. 584-585, 554-560.

[26] Carranza-Saavedra, D., Henao, C.P.S., Montoya, J.E.Z., 2021. Kinetic analysis and modeling of $\mathrm{L}$-valine production in fermentation batch from $E$. coli using glucose, lactose and whey as carbon sources. Biotechnol. Reports. 31, e00642.

[27] Carvalho, F., Prazeres, A.R., Rivas, J., 2013. Cheese whey wastewater: characterization and treatment. Sci. Total Environ. 445-446, 385-396.

[28] Castanha, R.F., Mariano, A.P., Morais, L.A.S.D., Scramin, S., Monteiro, R.T.R., 2014. Optimization of lipids production by Cryptococcus laurentii 11 using cheese whey with molasses. Braz. J. Microbiol. 45, 379-387.

[29] Castrillo, J.I., Kaliterna, J., Weusthuis, R.A., Van Dijken, J.P., Pronk, J.T., 1996. High-cell-density cultivation of yeasts on disaccharides in oxygen-limited batch cultures. Biotechnol. Bioeng. 49(6), 621-628.

[30] Castrillo, J.I., Ugalde, U.O., 1993. Patterns of energy metabolism and growth kinetics of Kluyveromyces marxianus in whey chemostat culture. Appl. Microbiol. Biotechnol. 40(2), 386393.

[31] Champagne, C.P., Goulet, J., 1988. Growth of bakers' yeast (Saccharomyces cerevisiae) in lactose-hydrolyzed cheese whey ultrafiltrate. Can. Inst. Food Sci. Technol. J. 21(5), 545548.

[32] Christensen, A.D., Kádár, Z., Oleskowicz-Popiel, P. Thomsen, M.H., 2011. Production of bioethanol from organic whey using Kluyveromyces marxianus. J. Ind. Microbiol. Biotechnol. 38(2), 283-289.

[33] Compagno, C., Tura, A., Ranzi, B.M., Martegani, E., 1993. Bioconversion of lactose/whey to fructose diphosphate with recombinant Saccharomyces cerevisiae cells. Biotechnol Bioeng. 42(3), 398-400.

[34] Costa, C.E., Romaní, A., Cunha, J.T., Johansson, B., Domingues, L., 2017. Integrated approach for selecting efficient Saccharomyces cerevisiae for industrial lignocellulosic fermentations: importance of yeast chassis linked to process conditions. Bioresour. Technol. 227, 24-34.

[35] Costa, D.A., De Souza, C.J., Costa, P.S., Rodrigues, M.Q., Dos Santos, A.F., Lopes, M.R., Genier, H.L., Silveira, W.B., Fietto, L.G., 2014. Physiological characterization of thermotolerant yeast for cellulosic ethanol production. Appl. Microbiol. Biotechnol. 98(8), 3829-3840.

[36] Cunha, J.T., Romaní, A., Costa, C.E., Sá-Correia, I. Domingues, L., 2019. Molecular and physiological basis of Saccharomyces cerevisiae tolerance to adverse lignocellulose-based process conditions. Appl. Microbiol. Biotechnol. 103(1), 159-175.

[37] Cunha, J.T., Soares, P.O., Baptista, S.L., Costa, C.E., Domingues, L., 2020. Engineered Saccharomyces cerevisiae for lignocellulosic valorization: a review and perspectives on bioethanol production. Bioengineered. 11(1), 883-903.

[38] Cunha, J.T., Gomes, D.G., Romaní, A., Inokuma, K. Hasunuma, T., Kondo, A., Domingues, L., 2021. Cell surface engineering of Saccharomyces cerevisiae for simultaneous valorization of corn cob and cheese whey via ethanol production. Energy Convers. Manage. 243, 114359.

[39] Cunha, M., Romaní, A., Carvalho, M., Domingues, L., 2018. Boosting bioethanol production from Eucalyptus wood by whey incorporation. Bioresour. Technol. 250, 256-264.

[40] D’Amato, D., Droste, N., Allen, B., Kettunen, M., Lähtinen, K., Korhonen, J., Leskinen, P., Matthies, B.D., Toppinen, A., 2017. Green, circular, bio economy: a comparative analysis of sustainability avenues. J. Clean. Prod. 168, 716-734.

[41] Daniel, H.J., Otto, R.T., Binder, M., Reuss, M., Syldatk, C., 1999. Production of sophorolipids from whey: development of a two-stage process with Cryptococcus curvatus ATCC 20509 and Candida bombicola ATCC 22214 using deproteinized whey concentrates as substrates. Appl. Microbiol. Biotechnol. 51(1), 40-45.

[42] Das, B., Sarkar, S., Maiti, S., Bhattacharjee, S., 2016. Studies on production of ethanol from cheese whey using Kluyveromyces marxianus. Mater. Today: Proc. 3(10), 32533257.

[43] De Felice, B., Blasi, V.O., de Castro, O., Cennamo, P., Martino, L., Trifuoggi, M., Condorelli, V., Di Onofrio, V., Guida, M., 2012. Genetic structure of a novel biofuelproducing microorganism community. J. Genet. 91(2), 183191.

[44] de Freitas, M.D.F.M. de, Hortêncio, L.C., Albuquerque, T.L. 
de, Rocha, M.V.P., Gonçalves, L.R.B., 2020. Simultaneous hydrolysis of cheese whey and lactulose production catalyzed by $\beta$-galactosidase from Kluyveromyces lactis NRRL Y1564. Bioprocess. Biosyst. Eng. 43(4), 711-722.

[45] del Río, P.G., Gomes-Dias, J.S., Rocha, C.M., Romaní, A., Garrote, G., Domingues, L., 2020. Recent trends on seaweed fractionation for liquid biofuels production. Bioresour. Technol. 299, 122613

[46] Demirel, B., Yenigun, O., Onay, T.T., 2005. Anaerobic treatment of dairy wastewaters: a review. Process Biochem. 40(8), 25832595.

[47] Díez-Antolínez, R., Hijosa-Valsero, M., Paniagua-García, A.I., Garita-Cambronero, J., Gómez, X., 2018. Yeast screening and cell immobilization on inert supports for ethanol production from cheese whey permeate with high lactose loads. PLoS One. 13(12), e0210002.

[48] Díez-Antolínez, R., Hijosa-Valsero, M., Paniagua A.I., Gómez, X., 2016. Very-high-gravity fermentation of non-supplemented cheese whey permeate by immobilized Kluyveromyces marxianus, in: Chemical Engineering Transactions. 49, pp. 529534.

[49] Dinika, I., Utama, G.L., 2019. Cheese whey as potential resource for antimicrobial edible film and active packaging production. Foods Raw Mater. 7(2), 229-239.

[50] Dinika, I., Verma, D.K., Balia, R., Utama, G.L., Patel, A.R., 2020. Potential of cheese whey bioactive proteins and peptides in the development of antimicrobial edible film composite: a review of recent trends. Trends Food Sci. Technol. 103, 57-67.

[51] Diniz, R.H., Rodrigues, M.Q., Fietto, L.G., Passos, F.M., Silveira, W.B., 2014. Optimizing and validating the production of ethanol from cheese whey permeate by Kluyveromyces marxianus UFV-3. Biocatal. Agric. Biotechnol. 3(2), 111-117.

[52] Domingues, L., Teixeira, J.A., Lima, N., 1999a. Construction of a flocculent Saccharomyces cerevisiae fermenting lactose. Appl. Microbiol. Biotechnol. 51(5), 621-626.

[53] Domingues, Lucília, Dantas, M.M., Lima, N., Teixeira, J.A., 1999b. Continuous ethanol fermentation of lactose by a recombinant flocculating Saccharomyces cerevisiae strain. Biotechnol. Bioeng. 64(6), 692-697.

[54] Domingues, L., Onnela, M.L., Teixera, J.A., Lima, N., Penttilä, M., 2000a. Construction of a flocculent brewer's yeast strain secreting Aspergillus niger $\beta$-galactosidase. Appl. Microbiol. Biotechnol. 54(1), 97-103.

[55] Domingues, L, Vicente, A.A., Lima, N., Teixeira, J.A., 2000 b. Applications of Yeast Flocculation in Biotechnological Processes. Biotechnol. Bioprocess Eng. 5(4), 288-305.

[56] Domingues, L., Lima, N., Teixeira, J.A., 2001. Alcohol production from cheese whey permeate using genetically modified flocculent yeast cells. Biotechnol. Bioeng. 72(5), 507514.

[57] Domingues, L., Teixeira, J., Penttilä, M., Lima, N., 2002. Construction of a flocculent Saccharomyces cerevisiae strain secreting high levels of Aspergillus niger $\beta$-galactosidase. Appl. Microbiol. Biotechnol. 58(5), 645-650.

[58] Domingues, L., Lima, N., Teixeira, J.A., 2005. Aspergillus niger $\beta$-galactosidase production by yeast in a continuous high cell density reactor. Process Biochem. 40(3-4), 1151-1154.

[59] Domingues, L., Guimarães, P.M., Oliveira, C., 2010. Metabolic engineering of Saccharomyces cerevisiae for lactose/whey fermentation. Bioeng. Bugs. 1(3), 164-171.

[60] Donaghy, J.A., McKay, A.M., 1994. Pectin extraction from citrus peel by polygalacturonase produced on whey. Bioresour.
Technol. 47(1), 25-28.

[61] Dragone, G., Mussatto, S.I., Oliveira, J.M., 2009 Characterisation of volatile compounds in an alcoholic beverage produced by whey fermentation. Food Chem. 112(4), 929-935.

[62] Dragone, G., Mussatto, S.I., e Silva, J.B.A., Teixeira, J.A., 2011. Optimal fermentation conditions for maximizing the ethanol production by Kluyveromyces fragilis from cheese whey powder. Biomass Bioenergy. 35(5), 1977-1982.

[63] Eş, I., Vieira, J.D.G., Amaral, A.C., 2015. Principles, techniques, and applications of biocatalyst immobilization for industrial application. Appl. Microbiol. Biotechnol. 99(5), 2065-2082.

[64] FAO, 2020. World milk production trends in 2018.

[65] Farahnak, F., Seki, T., Ryu, D.D.Y., Ogrydziak, D., 1986. Construction of lactose-assimilating and high-ethanolproducing yeasts by protoplast fusion. Appl. Environ. Microbiol. 51(2), 362-367.

[66] Faria, J.T.D., Rocha, P.F., Converti, A., Passos, F.M., Minim, L.A., Sampaio, F.C., 2013. Statistical investigation of Kluyveromyces lactis cells permeabilization with ethanol by response surface methodology. Braz. J. Microbiol. 44, 1067 1074.

[67] Farkas, C., Rezessy-Szabo, J.M., Gupta, V.K., Bujna, E., Pham, T.M., Pásztor-Huszár, K., Friedrich, L., Bhat, R., Thakur, V.K., Nguyen, Q.D., 2019. Batch and fed-batch ethanol fermentation of cheese-whey powder with mixed cultures of different yeasts. Energies. 12(23), 4495.

[68] Fassina, P., Nunes, G.Q., Adami, F.S., Goettert, M.I., Volken de Souza, C.F., 2019. Importance of cheese whey processing: supplements for sports activities-a review. Pol. J. Food Nutr. Sci. 69(1), 83-99.

[69] Fernández-Gutiérrez, D., Veillette, M., Giroir-Fendler, A., Ramirez, A.A., Faucheux, N., Heitz, M., 2017. Biovalorization of saccharides derived from industrial wastes such as whey: a review. Rev. Environ. Sci. Biotechnol. 16(1), 147-174.

[70] Ferreira, P.G., da Silveira, F.A., dos Santos, R.C.V., Genier, H.L.A., Diniz, R.H.S., Ribeiro, J.I., Fietto, L.G., Passos, F.M.L., da Silveira, W.B., 2015. Optimizing ethanol production by thermotolerant Kluyveromyces marxianus CCT 7735 in a mixture of sugarcane bagasse and ricotta whey. Food Sci. Biotechnol. 24(4), 1421-1427.

[71] Fonseca, G.G., Heinzle, E., Wittmann, C., Gombert, A.K., 2008. The yeast Kluyveromyces marxianus and its biotechnological potential. Appl. Microbiol. Biotechnol. 79(3), 339-354.

[72] Gabardo, S., Rech, R., Ayub, M.A.Z., 2012. Performance of different immobilized-cell systems to efficiently produce ethanol from whey: fluidized batch, packed-bed and fluidized continuous bioreactors. J. Chem. Technol. Biotechnol. 87(8), 1194-1201.

[73] Gänzle, M.G., Haase, G., Jelen, P., 2008. Lactose: crystallization, hydrolysis and value-added derivatives. Int. Dairy J. 18(7), 685-694.

[74] Goffrini, P., Ferrero, I., Donnini, C., 2002. Respirationdependent utilization of sugars in yeasts: a determinant role for sugar transporters. J. Bacteriol. 184(2), 427-432.

[75] Gomes, D.G., Teixeira, J.A., Domingues, L., 2021 a. Economic determinants on the implementation of a Eucalyptus wood biorefinery producing biofuels, energy and high added-value compounds. Appl. Energy. 303, 117662. 
[76] Gomes, D., Cruz, M., de Resende, M., Ribeiro, E., Teixeira, J., Domingues, L., 2021b. Very high gravity bioethanol revisited: main challenges and advances. Fermentation. 7(1), 38.

[77] Gomez-Ruiz, L., Garcia-Garibay, M., Barzana, E., 1988. Utilization of endo-polygalacturonase from Kluyveromyces fragilis in the clarification of apple juice. J. Food Sci. 53(4), 1236-1238.

[78] González-Siso, M.I., 1996. The biotechnological utilization of cheese whey: a review. Bioresour. Technol. 57(1), 1-11.

[79] González-Siso, M.I., García-Leiro, A., Tarrío, N., Cerdán, M.E., 2009. Sugar metabolism, redox balance and oxidative stress response in the respiratory yeast Kluyveromyces lactis. Microb. Cell Fact. 8(1), 46.

[80] González-Siso, M.I., Touriño, A., Vizoso, Á., Pereira-Rodríguez, Á., Rodríguez-Belmonte, E., Becerra, M., Cerdán, M.E., 2015. Improved bioethanol production in an engineered Kluyveromyces lactis strain shifted from respiratory to fermentative metabolism by deletion of NDI1. Microb. Biotechnol. 8(2), 319-330.

[81] Gosling, A., Stevens, G.W., Barber, A.R., Kentish, S.E., Gras, S.L., 2010. Recent advances refining galactooligosaccharide production from lactose. Food Chem. 121(2), 307-318.

[82] Guimarães, P.M., Teixeira, J.A., Domingues, L., 2010. Fermentation of lactose to bio-ethanol by yeasts as part of integrated solutions for the valorisation of cheese whey. Biotechnol. Adv. 28(3), 375-384.

[83] Guimarães, Pedro M. R., Le Berre, V., Sokol, S., François, J., Teixeira, J.A., Domingues, L., 2008a. Comparative transcriptome analysis between original and evolved recombinant lactose-consuming Saccharomyces cerevisiae strains. Biotechnol. J.: Healthcare Nutr. Technol. 3(12), 15911597.

[84] Guimarães, P.M., Teixeira, J.A., Domingues, L., $2008 b$. Fermentation of high concentrations of lactose to ethanol by engineered flocculent Saccharomyces cerevisiae. Biotechnol. Lett. 30(11), 1953-1958.

[85] Guimarães, Pedro M R, François, J., Luc, J., Teixeira, J.A., Domingues, L., 2008c. Adaptive evolution of a lactoseconsuming Saccharomyces cerevisiae recombinant. Appl. Environ. Microbiol. 74(6), 1748-1756.

[86] Gunasekaran, S., Ko, S., Xiao, L., 2007. Use of whey proteins for encapsulation and controlled delivery applications. J. Food Eng. 83(1), 31-40

[87] Guo, X., Zhou, J., Xiao, D., 2010. Improved ethanol production by mixed immobilized cells of Kluyveromyces marxianus and Saccharomyces cerevisiae from cheese whey powder solution fermentation. Appl. Biochem. Biotechnol. 160(2), 532-538.

[88] Guo, X., Wang, R., Chen, Y., Xiao, D., 2012. Intergeneric yeast fusants with efficient ethanol production from cheese whey powder solution: construction of a Kluyveromyces marxianus and Saccharomyces cerevisiae AY-5 hybrid. Eng. Life Sci. 12(6), 656-661.

[89] Hou, L., Jia, L., Morrison, H.M., Majumder, E.L.W., Kumar, D., 2021. Enhanced polyhydroxybutyrate production from acid whey through determination of process and metabolic limiting factors. Bioresour. Technol. 342, 125973.

[90] Janssens, J.H., Burris, N., Woodward, A., Bailey, R.B., 1983. Lipid-enhanced ethanol production by Kluyveromyces fragilis. Appl. Environ. Microbiol. 45(2), 598-602.

[91] Jenq, W., Speckman, R.A., Crang, R.E., Steinberg, M.P., 1989. Enhanced conversion of lactose to glycerol by Kluyveromyces fragilis utilizing whey permeate as a substrate. Appl. Environ. Microbiol. 55(3), 573-578.
[92] Jeong, Y.S., Vieth, W.R., Matsuura, T., 1991. Fermentation of lactose to ethanol with recombinant yeast in an immobilized yeast membrane bioreactor. Biotechnol. Bioeng. 37(6), 587-590.

[93] Jiang, L., Cui, H., Zhu, L., Hu, Y., Xu, X., Li, S., Huang, H., 2015. Enhanced propionic acid production from whey lactose with immobilized Propionibacterium acidipropionici and the role of trehalose synthesis in acid tolerance. Green Chem. 17(1), 250-259.

[94] Juraščík, M., Guimarães, P., Klein, J., Domingues, L., Teixeira, J., Markoš, J., 2006. Kinetics of lactose fermentation using a recombinant Saccharomyces cerevisiae strain. Biotechnol. Bioeng. 94(6), 1147-1154.

[95] Kasmi, M., 2018. Biological processes as promoting way for both treatment and valorization of dairy industry effluents. Waste Biomass Valorization. 9(2), 195-209.

[96] Kaur, R., Panesar, P.S., Singh, R.S., 2015. Utilization of whey for the production of $\beta$-galactosidase using yeast and fungal culture. World Acad. Sci. Eng. Technol. 9(7), 690-694.

[97] Kelbert, M., Romaní, A., Coelho, E., Pereira, F.B., Teixeira, J.A., Domingues, L., 2015. Lignocellulosic bioethanol production with revalorization of low-cost agroindustrial byproducts as nutritional supplements. Ind. Crop. Prod. 64, 1624.

[98] Knob, A., Izidoro, S.C., Lacerda, L.T., Rodrigues, A., de Lima, V.A., 2020. A novel lipolytic yeast Meyerozyma guilliermondii: efficient and low-cost production of acid and promising feed lipase using cheese whey. Biocatal. Agric. Biotechnol. 24, 101565.

[99] Kokkiligadda, A., Beniwal, A., Saini, P., Vij, S., 2016. Utilization of cheese whey using synergistic immobilization of $\beta$-galactosidase and Saccharomyces cerevisiae cells in dual matrices. Appl. Biochem. Biotechnol. 179(8), 1469-1484.

[100]Korhonen, H., 2009. Milk-derived bioactive peptides: from science to applications. J. Funct. Foods. 1(2), 177-187.

[101]Koushki, M., Jafari, M., Azizi, M., 2012. Comparison of ethanol production from cheese whey permeate by two yeast strains. J. Food Sci. Technol. 49(5), 614-619.

[102]Kumari, S., Panesar, P.S., Kaur, R., Bera, M.B., 2019. Statistical modeling of $\beta$-galactosidase production from nove yeast isolate using cheese whey. J. Sci. Ind. Res. 78(2), 81-85.

[103]Lappa, I.K., Kachrimanidou, V., Papadaki, A., Stamatiou, A., Ladakis, D., Eriotou, E., Kopsahelis, N., 2021. A comprehensive bioprocessing approach to foster cheese whey valorization: on-site $\beta$-galactosidase secretion for lactose hydrolysis and sequential bacterial cellulose production. Fermentation. 7(3), 184.

[104]Lappa, I.K., Papadaki, A., Kachrimanidou, V., Terpou, A., Koulougliotis, D., Eriotou, E., Kopsahelis, N., 2019. Cheese whey processing: integrated biorefinery concepts and emerging food applications. Foods. 8(8), 347.

[105]Lawton, M.R., Alcaine, S.D., 2019. Leveraging endogenous barley enzymes to turn lactose-containing dairy by-products into fermentable adjuncts for Saccharomyces cerevisiaebased ethanol fermentations. J. Dairy Sci. 102(3), 2044-2050.

[106]Lee, S.E., Lee, C.G., Kang, D.H., Lee, H.Y., Jung, K.H., 2012.Preparation of corncob grits as a carrier for immobilizing yeast cells for ethanol production. J. Microbiol. Biotechnol. 22(12), 1673-1680.

[107]Liu, J.J., Zhang, G.C., Oh, E.J., Pathanibul, P., Turner, T.L., Jin, Y.S., 2016. Lactose fermentation by engineered Saccharomyces cerevisiae capable of fermenting cellobiose. 
J. Biotechnol. 234, 99-104.

[108]Liu, J.J., Zhang, G.C., Kwak, S., Oh, E.J., Yun, E.J., Chomvong, K., Cate, J.H., Jin, Y.S., 2019. Overcoming the thermodynamic equilibrium of an isomerization reaction through oxidoreductive reactions for biotransformation. Nat. Commun. 10(1), 1-8.

[109]Magalhães, K., Pereira, M., Nicolau, A., Dragone, G., 2010. Production of fermented cheese whey-based beverage using kefir grains as starter culture: evaluation of morphological and microbial variations. Bioresour. Technol. 101(22), 8843-8850.

[110]Magalhães, K.T., Dias, D.R., de Melo Pereira, G.V., Oliveira, J.M., Domingues, L., Teixeira, J.A., de Almeida e Silva, J.B., Schwan, R.F., 2011a. Chemical composition and sensory analysis of cheese whey-based beverages using kefir grains as starter culture. Int. J. Food Sci. Technol. 46(4), 871-878.

[111]Magalhães, K.T., Dragone, G., De Melo Pereira, G.V., Oliveira, J.M., Domingues, L., Teixeira, J.A., e Silva, J.B.A., Schwan, R.F., 2011b. Comparative study of the biochemical changes and volatile compound formations during the production of novel whey-based kefir beverages and traditional milk kefir. Food Chem. 126(1), 249-253.

[112]Magalhães-Guedes, K., Rodrigues, A.K., Gervasio, I.M., Gervasio, I., Peraro Do Nascimento, A., Schwan, R.F., 2013. Ethanol production from deproteinized cheese whey fermentations by co-cultures of Kluyveromyces marxianus and Saccharomyces cerevisiae. Afr. J. Microbiol. Res. 7(13), 11211127.

[113]Mangiagalli, M., Lotti, M., 2021. Cold-active $\beta$-galactosidases: insight into cold adaptation mechanisms and biotechnological exploitation. Mar. Drugs. 19(1), 43.

[114]Mansour, M.H., Ghaly, A.E., Ben-Hassan, R.M., Nassar, M.A., 1993. Modeling batch production of single cell protein from cheese whey. Appl. Biochem. Biotechnol. 43(1), 1-14.

[115]Modler, W., 2009. Value-added components derived from whey. Am. Dairy Sci. Assoc. 1.

[116]Mollea, C., Marmo, L., Bosco, F., 2013. Valorisation of cheese whey, a by-product from the dairy industry, in: Food Industry. IntechOpen.

[117]Mudgil, D., Barak, S., 2019. Dairy-based functional beverages, in: Milk-Based Beverages. Woodhead Publishing, pp. 67-93.

[118]Murari, C.S., Machado, W.R.C., Schuina, G.L., Del Bianchi, V.L., 2019. Optimization of bioethanol production from cheese whey using Kluyveromyces marxianus URM 7404. Biocatal. Agric. Biotechnol. 20, 101182.

[119]Myers R.H., Montgomery, D.C., Anderson-Cook., C.M., 2016. Response surface methodology: process and product optimization using designed experiments, $4^{\text {th }}$ Edition. John Wiley \& Sons.

[120]Nagarajan, D., Nandini, A., Dong, C.D., Lee, D.J., Chang, J.S., 2020. Lactic acid production from renewable feedstocks using poly(vinyl alcohol)-Immobilized lactobacillus plantarum 23. Ind. Eng. Chem. Res. 59(39), 17156-17164.

[121]Nasrabadi, M.R.N., Razavi, S.H., 2011. Optimization of $\beta$ carotene production by a mutant of the lactosepositive yeast Rhodotorula acheniorum from whey ultrafiltrate. Food Sci. Biotechnol. 20(2), 445-454.

[122]Nayak, J., Pal, P., 2013. Transforming waste cheese-whey into acetic acid through a continuous membrane-integrated hybrid process. Ind. Eng. Chem. Res. 52(8), 2977-2984.

[123]Nehlin, J.O., Carlberg, M., Ronne, H., 1989. Yeast galactose permease is related to yeast and mammalian glucose transporters. Gene. 85(2), 313-319.

[124]Nicolás, P., Ferreira, M.L., Lassalle, V., 2019. A review of magnetic separation of whey proteins and potential application to whey proteins recovery, isolation and utilization. J. Food Eng. 246, 7-15.

[125]Obruca, S., Marova, I., Melusova, S., Mravcova, L., 2011. Production of polyhydroxyalkanoates from cheese whey employing Bacillus megaterium CCM 2037. Ann. Microbiol. 61(4), 947-953.

[126]Oda, Y., Nakamura, K., 2009. Production of ethanol from the mixture of beet molasses and cheese whey by a $2-$ deoxyglucose-resistant mutant of Kluyveromyces marxianus. FEMS Yeast Res. 9(5), 742-748.

[127]Oliveira, C., Teixeira, J.A., Lima, N., Da Silva, N.A., Domingues, L., 2007. Development of stable flocculent Saccharomyces cerevisiae strain for continuous Aspergillus niger $\beta$-galactosidase production. J. Biosci. Bioeng. 103(4), 318-324.

[128]Oliveira, C., Guimarães, P.M.R., Domingues, L., 2011. Recombinant microbial systems for improved $\beta$-galactosidase production and biotechnological applications. Biotechnol. Adv. 29(6), 600-609.

[129]Omwene, P.I., Yağcioğlu, M., Öcal-Sarihan, Z.B., Ertan, F., Keris-Sen, Ü.D., Karagunduz, A., Keskinler, B., 2021. Batch fermentation of succinic acid from cheese whey by Actinobacillus succinogenes under variant medium composition. 3 Biotech. 11(8), 1-10.

[130]Otto, R.T., Daniel, H.J., Pekin, G., Müller-Decker, K., Fürstenberger, G., Reuss, M., Syldatk, C., 1999. Production of sophorolipids from whey: II. product composition, surface active properties, cytotoxicity and stability against hydrolases by enzymatic treatment. Appl. Microbiol. Biotechnol. 52(4), 495-501.

[131]Pais, J., Serafim, L.S., Freitas, F., Reis, M.A., 2016. Conversion of cheese whey into poly(3-hydroxybutyrate-co3-hydroxyvalerate) by Haloferax mediterranei. New Biotechnol. 33(1), 224-230.

[132]Pandey, A., Srivastava, S., Rai, P., Duke, M., 2019. Cheese whey to biohydrogen and useful organic acids: a nonpathogenic microbial treatment by L. acidophilus. Sci. Rep. 9(1), 1-9.

[133]Panesar, P.S., Kennedy, J.F., Gandhi, D.N., Bunko, K., 2007. Bioutilisation of whey for lactic acid production. Food Chem. 105(1), 1-14.

[134]Parashar, A., Jin, Y., Mason, B., Chae, M., Bressler, D.C., 2016. Incorporation of whey permeate, a dairy effluent, in ethanol fermentation to provide a zero waste solution for the dairy industry. J. Dairy Sci. 99(3), 1859-1867.

[135]Paterson, A.H.J., 2009. Production and uses of lactose, in: Adv. Dairy Chem. pp. 105-120.

[136]Pereira, F.B., Guimarães, P.M., Teixeira, J.A., Domingues, L., 2011a. Robust industrial Saccharomyces cerevisiae strains for very high gravity bio-ethanol fermentations. J. Biosci. Bioeng. 112(2), 130-136.

[137]Pereira, F.B, Guimarães, P.M., Gomes, D.G., Mira, N.P., Teixeira, M.C., Sá-Correia, I., Domingues, L., 2011 b. Identification of candidate genes for yeast engineering to improve bioethanol production in very high gravity and lignocellulosic biomass industrial fermentations. Biotechnol. Biofuels. 4(1), 57

[138]Pescuma, M., de Valdez, G.F., Mozzi, F., 2015. Wheyderived valuable products obtained by microbial fermentation. Appl. Microbiol. Biotechnol. 99(15), $6183-$ 6196. 
[139]Petrova, V.Y., Kujumdzieva, A.V., 2010. Thermotolerant yeast strains producers of galacto-oligosaccharides. Biotechnol. Biotechnol. Equip. 24(1), 1612-1619.

[140]Perini, B.L.B., Souza, H.C.M., Kelbert, M., Apati, G.P., Pezzin, A.P.T., Schneider, A.L.S., 2013. Production of $\beta$-galactosidase from cheese whey using Kluyveromyces marxianus CBS 6556, Chem. Eng. Trans. 32, 991-996.

[141]Pignatelli, R., Vai, M., Alberghina, L., Popolo, L., 1998. Expression and secretion of Beta-galactosidase in Saccharomyces cerevisiae using the signal sequences of ggpi, the major yeast glycosylphosphatidylinositol-containing protein. Biotechnol. Appl. Biochem. 27(2), 81-88.

[142]Pinheiro, T., Lip, K.Y.F., García-Ríos, E., Querol, A., Teixeira, J., van Gulik, W., Guillamón, J.M., Domingues, L., 2020. Differential proteomic analysis by SWATH-MS unravels the most dominant mechanisms underlying yeast adaptation to nonoptimal temperatures under anaerobic conditions. Sci. Rep. 10(1), 1-17.

[143]Pires, A.F., Marnotes, N.G., Rubio, O.D., Garcia, A.C., Pereira, C.D., 2021. Dairy by-products: a review on the valorization of whey and second cheese whey. Foods. 10(5), 1067.

[144]Plessas, S., Bosnea, L., Psarianos, C., Koutinas, A.A., Marchant, R., Banat, I.M., 2008. Lactic acid production by mixed cultures of Kluyveromyces marxianus, Lactobacillus delbrueckii ssp. bulgaricus and Lactobacillus helveticus. Bioresour. Technol. 99(13), 5951-5955.

[145]Poch, O., L'Hôte, H., Dallery, V., Debeaux, F., , Fleer, R., Sodoyer, R., 1992Sequence of the Kluyveromyces lactis $\beta$ galactosidase: comparison with prokaryotic enzymes and secondary structure analysis. Gene. 118(1), 55-63.

[146]Porro, D., Martegani, E., Ranzi, B.M., Alberghina, L., 1992. Lactose/whey utilization and ethanol production by transformed Saccharomyces cerevisiae cells. Biotechnol. Bioeng. 39(8), 799805.

[147]Pouliot, Y., 2008. Membrane processes in dairy technology-From a simple idea to worldwide panacea. Int. Dairy J. 18(7), 735-740.

[148]Prazeres, A.R., Carvalho, F., Rivas, J., 2012. Cheese whey management: a review. J. Environ. Manage. 110, 48-68.

[149]Rama, G.R., Kuhn, D., Beux, S., Maciel, M.J., Volken de Souza, C.F.V., 2019. Potential applications of dairy whey for the production of lactic acid bacteria cultures. Int. Dairy J. 98, 25-37.

[150]Rao, R., Basak, N., 2021. Fermentative molecular biohydrogen production from cheese whey: present prospects and future strategy. Appl. Biochem. Biotechnol. 193, 2297-2330.

[151]Rapin, J.D., Marison, I.W., von Stockar, U., Reilly, P.J., 1994. Glycerol production by yeast fermentation of whey permeate. Enzyme Microb. Technol. 16(2), 143-150.

[152]Rocha, J.M., Guerra, A., 2020. On the valorization of lactose and its derivatives from cheese whey as a dairy industry by-product: an overview. Eur. Food Res. Technol. 246, 2161-2174.

[153]Rodríguez, Á.P., Leiro, R.F., Cristina, M.C., Cerdán, M.E., Siso, M.I.G., Becerra, M., 2006. Secretion and properties of a hybrid Kluyveromyces lactis-Aspergillus niger $\beta$-galactosidase. Microb. Cell Fact. 5(1), 41.

[154]Jelen, P., 2003. Whey processing, utilization and products. Encycl. Dairy Sci. Academic Press, London. pp. 2739-2745.

[155]Rollini, M., Musatti, A., Cavicchioli, D., Bussini, D., Farris, S., Rovera, C., Romano, D., De Benedetti, S., Barbiroli, A., 2020. From cheese whey permeate to Sakacin-A/bacterial cellulose nanocrystal conjugates for antimicrobial food packaging applications: a circular economy case study. Sci. Rep. 10(1), 114.
[156]Roohina, F., Mohammadi, M., Najafpour, G.D., 2016. Immobilized Kluyveromyces marxianus cells in carboxymethyl cellulose for production of ethanol from cheese whey: experimental and kinetic studies. Bioprocess. Biosyst. Eng. 39(9), 1341-1349.

[157]Rosa, J.C.C., Colombo, L.T., Alvim, M.C.T., Avonce, N., Van Dijck, P., Passos, F.M.L., 2013. Metabolic engineering of Kluyveromyces lactis for L-ascorbic acid (vitamin C) biosynthesis. Microb. Cell Fact. 12(1), 59.

[158]Rubio-Texeira, M., Castrillo, J.I., Adam, A.C., Ugalde, U.O., Polaina, J., 1998. Highly efficient assimilation of lactose by a metabolically engineered strain of Saccharomyces cerevisiae. Yeast. 14(9), 827-837.

[159]Ryan, M.P., Walsh, G., 2016. The biotechnological potential of whey. Rev. Environ. Sci. Biotechnol. 15(3), 479-498.

[160]Ryu, Y.W., Jang, H.W., Lee, H.S., 1991. Enhancement of ethanol tolerance of lactose assimilating yeast strain by protoplast fusion. J. Microbiol. Biotechnol. 1(3), 151-156.

[161]Saini, P., Beniwal, A., Kokkiligadda, A., Vij, S., 2017 a. Evolutionary adaptation of Kluyveromyces marxianus strain for efficient conversion of whey lactose to bioethanol. Process Biochem. 62, 69-79.

[162]Saini, P., Beniwal, A., Vij, S., 2017b. Comparative analysis of oxidative stress during aging of Kluyveromyces marxianus in synthetic and whey media. Appl. Biochem. Biotechnol. 183(1), 348-361.

[163]Sampaio, F.C., Faria, J.T., Silva, M.F., de Souza Oliveira, R.P., Converti, A., 2019. Cheese whey permeate fermentation by Kluyveromyces lactis: a combined approach to wastewater treatment and bioethanol production. Environ. Technol. 41(24), 3210-3218.

[164]Sansonetti, S., Curcio, S., Calabrò, V., Iorio, G., 2009. Bioethanol production by fermentation of ricotta cheese whey as an effective alternative non-vegetable source. Biomass Bioenergy. 33(12), 1687-1692.

[165]Sanz, P., Randez-Gil, F., Prieto, J.A., 1994. Molecular characterization of a gene that confers 2-deoxyglucose resistance in yeast. Yeast. 10(9), 1195-1202.

[166]Saqib, S., Akram, A., Halim, S.A., Tassaduq, R., 2017. Sources of $\beta$-galactosidase and its applications in food industry. 3 Biotech. 7(1), 79.

[167]Schultz, N., Chang, L., Hauck, A., Reuss, M., Syldatk, C., 2006. Microbial production of single-cell protein from deproteinized whey concentrates. Appl. Microbiol. Biotechnol. 69(5), 515-520.

[168]Seo, Y.H., Lee, I., Jeon, S.H., Han, J.I., 2014. Efficient conversion from cheese whey to lipid using Cryptococcus curvatus. Biochem. Eng. J. 90, 149-153.

[169]Silva, A.C., Guimarães, P.M., Teixeira, J.A., Domingues, L., 2010. Fermentation of deproteinized cheese whey powder solutions to ethanol by engineered Saccharomyces cerevisiae: effect of supplementation with corn steep liquor and repeatedbatch operation with biomass recycling by flocculation. J. Ind. Microbiol. Biotechnol. 37(9), 973-982.

[170]Silveira, W.B., Passos, F.J.V., Mantovani, H.C., 2005. Ethanol production from cheese whey permeate by Kluyveromyces marxianus UFV-3: a flux analysis of oxidoreductive metabolism as a function of lactose. Enzyme Microb. Technol. 36(7), 930-936.

[171]Silveira, F.A., Oliveira Soares, D.L., Bang, K.W., Balbino, T.R., de Moura Ferreira, M.A., Diniz, R.H.S., de Lima, L.A., Brandão, M.M., Villas-Bôas, S.G., da Silveira, W.B., 2020. 
Assessment of ethanol tolerance of Kluyveromyces marxianus CCT 7735 selected by adaptive laboratory evolution. Appl. Microbiol. Biotechnol. 104(17), 7483-7494.

[172]Smithers, G.W., 2008. Whey and whey proteins-From "gutter-togold". Int. Dairy J. 18(7), 695-704.

[173]Smithers, G.W., 2015. Whey-ing up the options-yesterday, today and tomorrow. Int. Dairy J. 48, 2-14.

[174]Snoek, I.I., Steensma, H., 2006. Why does Kluyveromyces lactis not grow under anaerobic conditions? comparison of essential anaerobic genes of Saccharomyces cerevisiae with the Kluyveromyces lactis genome. FEMS yeast Res. 6(3), 393-403.

[175]Soupioni, M., Golfinopoulos, A., Kanellaki, M., Koutinas, A.A., 2013. Study of whey fermentation by kefir immobilized on low cost supports using ${ }^{14} \mathrm{C}$-labelled lactose. Bioresour. Technol. 145, 326-330.

[176]Sreekrishna, K., Dickson, R.C., 1985. Construction of strains of Saccharomyces cerevisiae that grow on lactose. Proc. Natl. Acad. Sci. U.S.A. 82(23), 7909-7913.

[177]Sun, H., You, S., Wang, M., Qi, W., Su, R., He, Z., 2016. Recyclable strategy for the production of high-purity galactooligosaccharides by Kluyveromyces lactis. J. Agric. Food Chem. 64(28), 5679-5685.

[178]Taskin, M., Saghafian, A., Aydogan, M.N., Arslan, N.P., 2015. Microbial lipid production by cold-adapted oleaginous yeast Yarrowia lipolytica B9 in non-sterile whey medium. Biofuels, Bioprod. Biorefin. 9(5), 595-605.

[179]Taya, M., Honda, H., Kobayashi, T., 1984. Lactose-utilizing hybrid strain derived from Saccharomyces cerevisiae and Kluyveromyces lactis by protoplast fusion. Agric. Biol. Chem. 48(9), 2239-2243.

[180]Terrell, S.L., Bernard, A., Bailey, R.B., 1984. Ethanol from whey: continuous fermentation with a catabolite repressionresistant Saccharomyces cerevisiae mutant. Appl. Environ. Microbiol. 48(3), 577-580.

[181]Tomaszewska, M., Białończyk, L., 2016. Ethanol production from whey in a bioreactor coupled with direct contact membrane distillation, in: Catal. Today. Elsevier. 268 pp. 156-163.

[182]Turner, T.L., Kim, E., Hwang, C., Zhang, G., Liu, J., Jin, Y., 2017. Short communication: conversion of lactose and whey into lactic acid by engineered yeast. J. Dairy Sci. 100(1), 124-128.

[183]Uncu, O.N., Cekmecelioglu, D., 2011. Cost-effective approach to ethanol production and optimization by response surface methodology. Waste Manage. 31(4), 636-643.

[184]Castillo, V.M., Pachapur, L., Kaur Brar, S., Naghdi, M., Arriaga, S., Ávalos Ramirez, A., 2020. Yeast-driven whey biorefining to produce value-added aroma, flavor, and antioxidant compounds: technologies, challenges, and alternatives. Crit. Rev. Biotechnol. 40(7), 930-950.

[185]van Dijk, M., Mierke, F., Nygård, Y., Olsson, L., 2020. Nutrientsupplemented propagation of Saccharomyces cerevisiae improves its lignocellulose fermentation ability. AMB Express. 10(1), 1-10.

[186]van Ooyen, A.J., Dekker, P., Huang, M., Olsthoorn, M.M., Jacobs, D.I., Colussi, P.A., Taron, C.H., 2006. Heterologous protein production in the yeast Kluyveromyces lactis. FEMS Yeast Res. 6(3), 381-392.

[187]Venturini, M., Morrione, A., Pisarra, P., Martegani, E., Vanoni, M., 1997. In Saccharomyces cerevisiae a short amino acid sequence facilitates excretion in the growth medium of periplasmic proteins. Mol. Microbiol. 23(5), 997-1007.

[188]Vyas, S., Chhabra, M., 2019. Assessing oil accumulation in the oleaginous yeast Cystobasidium oligophagum $\mathrm{JRC}_{1}$ using dairy waste cheese whey as a substrate. 3 Biotech. 9(5), 173.

[189]Wanarska, M., Kur, J., 2012. A method for the production of D-tagatose using a recombinant Pichia pastoris strain secreting $\quad \beta$-D-galactosidase from Arthrobacter chlorophenolicus and a recombinant L-arabinose isomerase from Arthrobacter sp. 22c. Microb. Cell Fact. 11(1), 113.

[190]Watanabe, T., Shinozaki, Y., Suzuki, K., Koitabashi, M., Yoshida, S., Sameshima-Yamashita, Y., Kuze Kitamoto, H.K., 2014. Production of a biodegradable plastic-degrading enzyme from cheese whey by the phyllosphere yeast Pseudozyma antarctica GB-4(1)W. J. Biosci. Bioeng. 118(2), 183-187.

[191]Wen-qiong, W., Yun-chao, W., Xiao-feng, Z., Rui-xia, G., Mao-lin, L., 2019. Whey protein membrane processing methods and membrane fouling mechanism analysis. Food Chem. 289, 468-481.

[192]Wolf, K., Zimmermann, M., Sipiczki, M., 1996. Protoplast fusion of yeasts, in: Nonconventional yeasts in biotechnology. Springer Berlin Heidelberg, pp. 83-99.

[193]Yadav, J.S.S., Bezawada, J., Ajila, C.M., Yan, S., Tyagi, R.D., Surampalli, R.Y., 2014. Mixed culture of Kluyveromyces marxianus and Candida krusei for single-cell protein production and organic load removal from whey. Bioresour. Technol. 164, 119-127.

[194] Yadav, J.S.S., Yan, S., Pilli, S., Kumar, L., Tyagi, R.D., Surampalli, R.Y., 2015. Cheese whey: a potential resource to transform into bioprotein, functional/nutritional proteins and bioactive peptides. Biotechnol. Adv. 33(6), 756-774.

[195]You, K.M., Rosenfield, C.L., Knipple, D.C., 2003. Ethanol tolerance in the yeast Saccharomyces cerevisiae is dependent on cellular oleic acid content. Appl. Environ. Microbiol. 69(3), 1499-1503.

[196] You, S., Zhang, J., Yin, Q., Qi, W., Su, R., He, Z., 2017. Development of a novel integrated process for co-production of B-galactosidase and ethanol using lactose as substrate. Bioresour. Technol. 230, 15-23.

[197]Zafar, S., Owais, M., 2006. Ethanol production from crude whey by Kluyveromyces marxianus. Biochem. Eng. J. 27(3), 295-298.

[198]Zara, G., Angelozzi, D., Belviso, S., Bardi, L., Goffrini, P., Lodi, T., Budroni, M., Mannazzu, I., 2009. Oxygen is required to restore flor strain viability and lipid biosynthesis under fermentative conditions. FEMS Yeast Res. 9(2), 217-225.

[199]Zhou, X., Hua, X., Huang, L., Xu, Y., 2019. Bio-utilization of cheese manufacturing wastes (cheese whey powder) for bioethanol and specific product (galactonic acid) production via a two-step bioprocess. Bioresour. Technol. 272, 70-76.

[200]Zikmanis, P., Kolesovs, S., Semjonovs, P., 2020. Production of biodegradable microbial polymers from whey. Bioresour. Bioprocess. 7(1), 36.

[201]Zohri, A.N.A., Ragab, S.W., Mekawi, M.I., Mostafa, O.A.A., 2017. Comparison between batch, fed-batch, semi-continuous and continuous techniques for bio-ethanol production from a mixture of egyptian cane and beet molasses. Sugar J. 9, 89111.

[202]Zoppellari, F., Bardi, L., 2013. Production of bioethanol from effluents of the dairy industry by Kluyveromyces marxianus. N. Biotechnol. 30(6), 607-613.

[203]Zotta, T., Solieri, L., Iacumin, L., Picozzi, C., Gullo, M., 2020 Valorization of cheese whey using microbial fermentations. Appl. Microbiol. Biotechnol. 104(7), 2749-2764. 
[204]Zou, J., Guo, X., Shen, T., Dong, J., Zhang, C., Xiao, D., 2013. Construction of lactose-consuming Saccharomyces cerevisiae for lactose fermentation into ethanol fuel. J. Ind. Microbiol. Biotechnol. 40(3-4), 353-363.

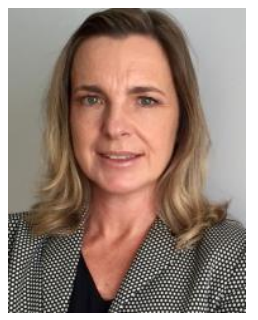

Lucília Domingues received her Ph.D. in Chemical and Biological Engineering in 2001 from University of Minho, Portugal. Currently, she is Associate Professor with Habilitation at the Department of Biological Engineering at University of Minho, Associate Director of the Centre of Biological Engineering of the same university and leads the Molecular Biotechnology and Microbial Physiology team (LAB Twitter: https://twitter.com/LBMlab). Her research work has been driven by the use of molecular biotechnology tools for microbial strain development and intensification of bioprocesses with focus on the utilization of renewable substrates and eco-sustainable production of bio-based chemicals and fuels with applications on the food, energy, chemical and/or biomedical industries. Her research profile is available at https://orcid.org/00 00-0003-1089-7627

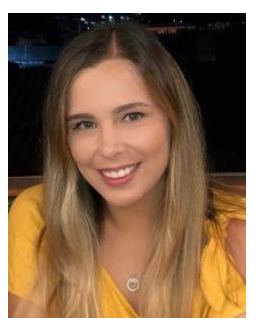

Sara L. Baptista is a PhD student at the Centre of Biological Engineering, University of Minho, Braga, Portugal. She is graduated in Applied Biology and has a Master's degree in Bioengineering. Her research work is focused on the development of yeast strains for the efficient utilisation of renewable substrates and ecosustainable production of natural sweeteners. Her research profile is available at https://orcid.org/00000002-7921-3628
[205]Zou, J., Chen, X., Hu, Y., Xiao, D., Guo, X., Chang, X., Zhou, L., 2021. Uncoupling glucose sensing from GAL metabolism for heterologous lactose fermentation in Saccharomyces cerevisiae. Biotechnol. Lett., 43(8), 1607-1616.

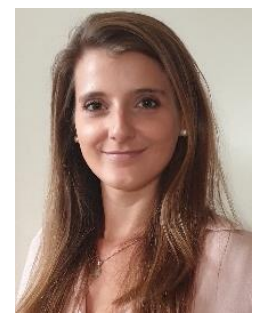

Patrícia Carvalho is graduated in Biochemistry by the University of Minho and has a Master's degree in Applied Biochemistry with expertise in Biomedicine. She is a fellowship researcher in the Centre of Biological Engineering, with a focus in metabolic engineering, for the development of robust yeast strains able to use lactose as a carbon source. Her research profile is available at https://orcid.org/my-orcid?orcid=0000-0003-43921371

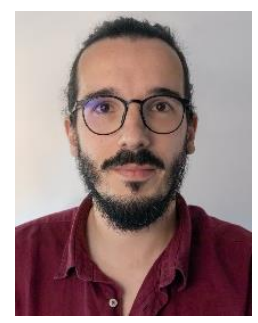

Carlos E. Costa is a PhD student at the Centre of Biological Engineering, University of Minho, Braga, Portugal. He is graduated in Biochemistry and has a Master's degree in Molecular Biology and Biotechnology. He was a fellowship researcher in the European project YeasTemptation, centred on the identification and development of thermotolerant robust yeast strains. His research focuses mainly on metabolic engineering and yeast fermentation for the production of value-added chemicals, such as resveratrol, from carbon sources. His research profile is available at https://.org/0000-0001-6842-8511 